Max-Planck-Institut für demografische Forschung

Max Planck Institute for Demographic Research

Konrad-Zuse-Strasse $1 \cdot$ D-18057 Rostock · GERMANY

Tel +49 (0) 3812081 - 0; Fax +49 (0) 3812081 - 202;

http://www.demogr.mpg.de

MPIDR WORKING PAPER WP 2007-018

MAY 2007 (REVISED JULY 2007)

Family dynamics

in pre- and post-transition Romania:

a life-table description

Cornelia Muresan (muresan@demogr.mpg.de)

This working paper has been approved for release by: Hill Kulu (kulu@demogr.mpg.de)

Deputy Head of the Laboratory of Contemporary European Fertility and Family Dynamics.

(C) Copyright is held by the authors.

Working papers of the Max Planck Institute for Demographic Research receive only limited review. Views or opinions expressed in working papers are attributable to the authors and do not necessarily reflect those of the Institute. 


\section{Content}

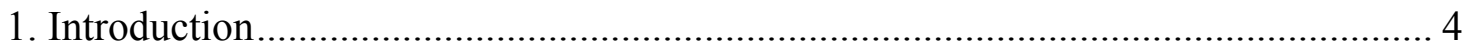

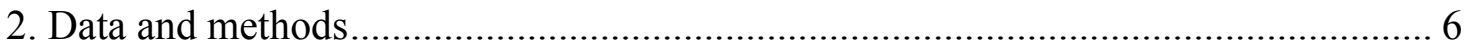

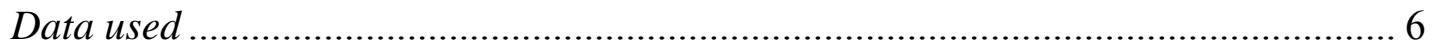

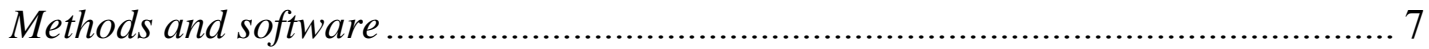

3. Country background........................................................................................... 9

Period fertility level: long-lasting low fertility, early childbearing under question but no late type fertility ........................................................................................ 11

Postponement of childbearing and marriage: better unmarried than childless...... 13 Weakening of marriage as an institution: marriage rates dropped, but the stability

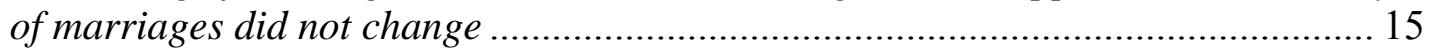

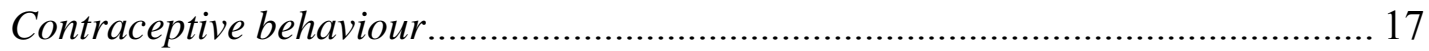

Early stage of the Second Demographic Transition in Romania ............................ 18

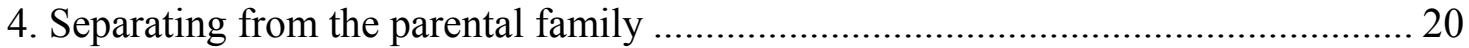
Leaving the parental home ................................................................................. 20 Separating from the parental family: before first union formation, at first union formation, or after union formation?...................................................................... 23

5. Forming a first union ....................................................................................... 29

First marriage: single decrement perspective ..................................................... 29

First union: single decrement perspective ............................................................. 32

First union: direct marriage or cohabitation? ...................................................... 34

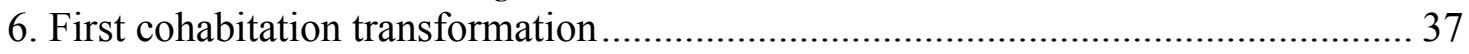

Duration of first cohabitation: marriage or separation? ....................................... 38

Transformation of first cohabitation: childbearing, separation or marriage? ........ 41

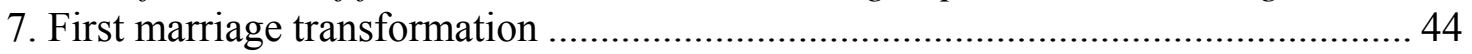

Duration of first marriage: divorce or partner's death? ......................................... 45

Transformation of first marriage: childbearing or divorce?.................................... 48

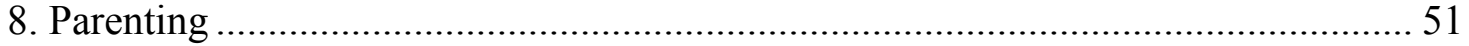

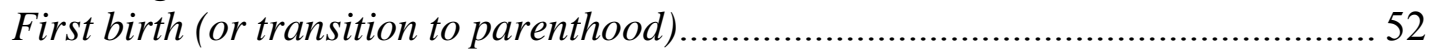

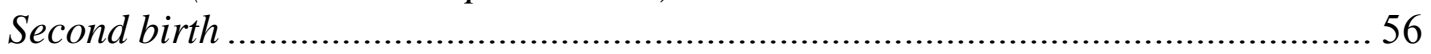

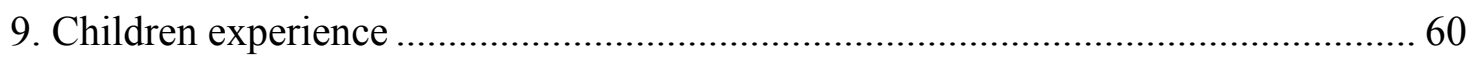

Distribution of birth by union status of the parent ……………….............................. 60

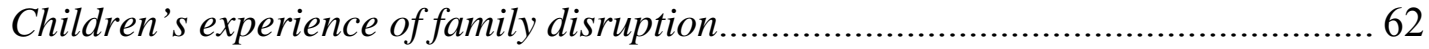

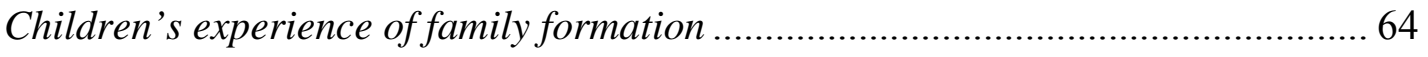

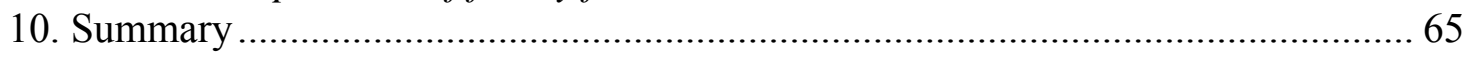

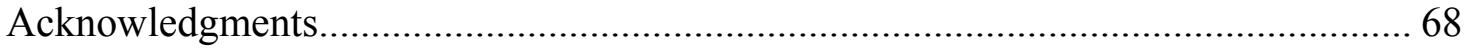

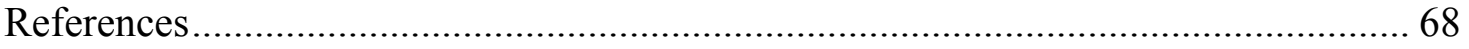




\title{
Family dynamics in pre- and post-transition Romania: a life-table description
}

\author{
Cornelia Mureşan ${ }^{1}$
}

\begin{abstract}
This study presents a life-table description of a wide range of events concerning family formation and fertility in Romania, by contrasting two different periods in Romanian history: a period of authoritarian regime and centrally planned economy (1980-1989) and a period of democratic political regime and market-oriented economy (1996-2005). A large number of single- and multi-decrement life tables deals with leaving home, separating from the parental family, forming first union, direct marriage, cohabitation, childbearing in the context of cohabitation or marriage, separation and divorce, and parenting (first birth and second birth). Perspectives of men and women, as well those of couples and children, are considered. The main data source we used here is Generations and Gender Survey carried out in Romania in 2005. Our life-table analysis confirms the early stage of the Second Demographic Transition in Romania. However, in European context it still remains a society highly valuing marriage and childbearing, despite the evidence in family behaviour changes which have accompanied political and socioeconomical transformations after the fall of communist regime.
\end{abstract}

\footnotetext{
${ }^{1}$ University Babeş-Bolyai, B-dul 21 decembrie 1989, nr.128, Cluj-Napoca, Romania; Email: cmuresan8@yahoo.com. This paper was written while the author was guest reserarcher at Max Planck Institute for Demographic Research, Konrad-Zuse-Str 1, Rostock, Germany; Email: muresan@demogr.mpg.de
} 


\section{Introduction}

After Dirk van de Kaa introduced the terminology "second demographic transition" (Van de Kaa 1987) in 1987, many authors contested or agreed with the term, and we certainly witnessed an upsurge in family dynamic research. Changes in how people tend to organize their family life and diversification of life options were reported mainly in developed countries, and a large amount of literature has tried to explain new patterns of behaviour.

The changes in union formation, parenting and union dissolution, which began in the second half of 1960, were well documented in western European societies, but they were noticed in all European countries. After the fall of socialist-regimes (in 1989), a more rapid pace of similar demographic changes were observed in all former Eastern-bloc countries, as if they would "have to recuperate" the delay regarding the new familyrelated patterns and not only the delay related to the economic sector or the sociopolitical organization. Every country has its specificity regarding family behaviour and related changes, and each of them deserves attention, however, in this paper we focus on Romania.

Nevertheless, the aim of this study is not to provide an investigation of the determinants of family demographic behaviour, since first of all we still need a better basic description of the actual state of family dynamics and of life courses of individuals in Romania, both during socialism and post-socialist times. However, we focus on the main shifts in demographic behaviour described in the Second Demographic Transition Theory, as was elaborated by Lesthaeghe and Van de Kaa in their later studies (e.g. Lesthaeghe 1995, 1998; Van de Kaa 2001).

The richness of data collected by the Generation and Gender Survey in 2005 in Romania offers the chance for a deeper look into family-related behavioural changes, for the first time in the data collection history of this country. We can look not only at marriages, births and divorces, but also at leaving the parental home, entries in and exits from alternative (to marriage) union forms like cohabitation, we can study children's 
experience on family life and we can adopt either period or cohort approaches. From a methodological point of view we preferred to follow the approach that Andersson and Philipov opened in their series of life-table descriptions based on FFS data carried out on 15 countries at the end of the $20^{\text {th }}$ century (Andersson and Philipov 2002). Their study seems to have become a standard in description techniques for the more recent GGS data, since the work for Bulgaria and Russia has already been done (Philipov and Jasilioniene 2007).

Our study is organized into 10 sections. Following the introduction, section 2 deals with data and methods. Section 3 provides a country background comparing Romania with three other countries within the framework of the Second Demographic Transition Theory, and using other data than the GGS. The ensuing sections take the demographic events belonging to family dynamics, one by one and study different research questions mainly dealing with the differences between socialist times and after one and a half decades of transition. Leaving the parental home and more generally separating from the parental family is studied in section 4. Section 5 studies first union formation, trying to contrast development of cohabitation with direct marriage. Section 6 is dedicated to first union started as consensual union and studies the duration of cohabitation, on the one hand, and the transformation of cohabitation from childless status to parenthood or from being together to separation, on the other hand. The same framework is also applied to first marriage, in section 7. First we study the duration of marriage, and then we focus on the transition to first birth or to divorce. Section 8 concentrates on the transition to parenthood of men and women. Transition from first birth to second birth is treated separately in the same section. In section 9 we switch the perspective from the adults to the perspective of children and we describe the familial context in which they were born. We deal with parental disruption experience of children born into union and with union formation experience of children born out of union. At the end we have a summary section (section 10). 


\section{Data and methods}

\section{Data used}

Two data sources are used in this study: Generations and Gender Survey 2005 Romania and Recent Demographic Developments in Europe 2004.

With the one exception of the country background section, our study is based on data collected by the Generations and Gender Survey (GGS) at the end of $2005^{2}$. The sample consists of 11,986 respondents (5,977 men and 6,009 women) aged from 18 to 79 completed years at the time of interview. At the time of writing this study, only the unweighted dataset was available. More precisely this means that we used data that underestimates the youth (18-29-years old) and overestimates the age groups older than 50 by about $12 \%$. There are also additional overestimates by gender: Older women (6069 years old) and middle-aged men (40-49) are over-represented (by $4 \%$ and $1 \%$, respectively). Despite the inconvenience we still can safely use our life-tables, since they control for age, and since each age group sub-sample size is large enough to assure a good representation of the Romanian population. We have cleaned the event histories with a set of adapted versions of Stata programmes, developed by Phillipov for Bulgarian and Russian GGS data sets. We have found very few errors, so there is no reason to report about them here.

In the GGS questionnaire, reporting every date of an event by the year and the month when it occurred was requested. Consequently, our timing estimates have the precision of a month. We considered the middle of the month as the exact time of an event.

Our second data source is the volume of statistical tables containing a series of standard, country specific, demographic indicators, published on a yearly basis by the Council of Europe: Recent Demographic Developments in Europe (2004).

\footnotetext{
${ }^{2}$ Generations and Gender Survey (GGS) was carried out in Romania within the framework of the Generations and Gender Programme (GGP) with the financial support of the United Nation Fund for Population Activities (UNFPA) and the Max Planck Institute for Demographic Research (MPIDR). More details about the programme can be found on the website of Population Activities Unit of the United Nations Economic Commission for Europe (UNECE PAU), http://www.unece.org/pau/ggp, which is the coordinator of the whole project, and also on the website of MPIDR, http://www.demogr.mpg.de .
} 
More detailed information about the kind of indicators used and countries of interest are in the following section.

\section{Methods and software}

Our descriptive measures are based on well-known life-table techniques. Not only are they well-known ${ }^{3}$, the entire set of tables are also suitable for family behaviour descriptions, based on micro-level, individual, longitudinal, survey data, which were developed by Andersson and Philipov (2002). They exemplified the issue of building many life-tables, for 14 European countries and the USA, all based on data gathered by Fertility and Family Surveys (FFS) which were carried out in the 1990s. Moreover, we have an example of life-tables constructed specifically with GGS data, by Philipov and Jasilioniene (2007) who published a comparison of Bulgaria and Russia using this technique. Our study closely follows their set of tables, since their version better describes a post-socialist country such as Romania, than the wider range of tables developed on FFS. However, we also introduced a number of new kinds of life-tables, such as those referring to first cohabitation and first marriage transformations.

The tables contain Kaplan-Maier estimates of cumulative percent experiencing a specific event at different, listed, exact ages (or exact durations were that the case). They are indicators of level reached at a specified age. When the level is not expected to increase after this age, we refer to as "ultimate" level reached by the synthetic cohort. Other indicators in our tables are well-known timing indicators: mean age (or duration), median age, first decile, first quartile or third quartile.

Our figures show estimates of hazard risks, i.e. ratios of number of occurrences to number of person-years (but monthly precision), during a specific interval of time; in our case four years. Hazard risks express the instant (monthly) force of transition from a specific "origin" status to a "destination" status, and they are calculated only for real cohorts in order to evaluate behavioural changes.

\footnotetext{
${ }^{3}$ For more details one can, for example, look in the textbook by Preston et al. (2001) or a more concise description in Hoem (2001).
} 
GGS data permits a wide variety of choices regarding either periodisation or birth cohort grouping. According to our study aim, which is to contrast family behaviours before and after the transition in 1989, we have chosen two ten-year long periods: 1980-1989 and 1996-2006. The first period contains the last ten years of the socialism-state and the second period contains the last ten (from a total of 15) years of the democratic-state, covered by the sample. Table 2.1 shows the number of observations in each synthetical cohort, by the event studied.

Table 2.1. Number of observations in the sample, by synthetical cohort and event studied

\begin{tabular}{|c|c|c|c|c|}
\hline & Men & Women & Couples & Children \\
\hline \multicolumn{5}{|l|}{ 1980-1989 } \\
\hline leaving parental home & 3245 & 2578 & & \\
\hline separating from parental family & 2920 & 2421 & & \\
\hline entry into first marriage & 3458 & 2912 & & \\
\hline union formation & 3406 & 2824 & & \\
\hline ending first cohabitation & & & 562 & \\
\hline transforming first cohabitation & & & 464 & \\
\hline ending first marriage & & & 3879 & \\
\hline transforming first marriage & & & 2867 & \\
\hline entry into parenthood & 3915 & 3214 & & \\
\hline second birth & 1746 & 2070 & & \\
\hline distribution of births (1st-3rd) & & & & 4620 \\
\hline children exp of parental disruption & & & & 5180 \\
\hline children exp of family formation & & & & 368 \\
\hline \multicolumn{5}{|l|}{$1996-2005$} \\
\hline leaving parental home & 1684 & 1014 & & \\
\hline separating from parental family & 1295 & 860 & & \\
\hline entry into marriage & 1814 & 1334 & & \\
\hline union formation & 1678 & 1185 & & \\
\hline ending first cohabitation & & & 688 & \\
\hline transforming first cohabitation & & & 538 & \\
\hline ending first marriage & & & 4382 & \\
\hline transforming first marriage & & & 2258 & \\
\hline entry into parenthood & 2336 & 1680 & & \\
\hline second birth & 2044 & 2211 & & \\
\hline distribution of births (1st-3rd) & & & & 2276 \\
\hline children exp of parental disruption & & & & 8586 \\
\hline children exp of family formation & & & & 193 \\
\hline
\end{tabular}

Beside the period perspective, which we prefer to use in order to contrast socialist and post-socialist times, we add, sometimes, findings from the birth cohort perspective.

All the estimates were produced with Stata Release 9.1 programmes which were adapted to Romanian GGS, and which were initially written for Bulgaria by Philipov. In addition 
to the statistical package Stata 9.1 (StataCorp 2005), we used the programme stcompet2 (Coviello and Boggess 2004) for estimating competing-risk cumulative incidence functions.

\section{Country background}

Before we actually present the outcomes resulting from the GGS data set, let us see what the classical indicators, constructed from vital statistics data, show about the advancements of Romania in the more general European trends related to family behaviour.

Table 3.1. Indicators of demographic change during the Second Demographic Transition

\begin{tabular}{|c|c|c|}
\hline Indicator & First phase & Second phase \\
\hline \multicolumn{3}{|l|}{ Period fertility level } \\
\hline 1. Total fertility rate (TFR) & $\begin{array}{l}\text { TFR decline below } 1.8 \text { for a } \\
\text { period of } 5 \text { years or more }\end{array}$ & - \\
\hline 2. TFR of women below age 25 & $\begin{array}{l}\text { Decline by } 20 \% \text { relative to the } \\
1965 \text { level }\end{array}$ & $\begin{array}{l}\text { Decline by } 60 \% \text { relative to the } \\
1965 \text { level }\end{array}$ \\
\hline 3. TFR of women aged $30+$ & Lowest level reached after 1965 & $\begin{array}{l}\text { Increase by } 20 \% \text { relative to the } \\
\text { lowest level reached after } 1965\end{array}$ \\
\hline \multicolumn{3}{|c|}{ Postponement of childbearing and marriage } \\
\hline $\begin{array}{l}\text { 4. Mean age of mother at first } \\
\text { childbirth }\end{array}$ & $\begin{array}{l}\text { Onset of the increase lasting at } \\
\text { least } 5 \text { years }\end{array}$ & $\begin{array}{l}\text { Increase by } 2 \text { years relative to the } \\
\text { lowest post- } 1965 \text { level }\end{array}$ \\
\hline $\begin{array}{l}\text { 5. Mean age of women at first } \\
\text { marriage }\end{array}$ & $\begin{array}{l}\text { Onset of the increase lasting at } \\
\text { least } 5 \text { years }\end{array}$ & $\begin{array}{l}\text { Reaching higher level than the } \\
\text { mean age at first birth }\end{array}$ \\
\hline \multicolumn{3}{|c|}{ Weakening of marriage as an institution } \\
\hline $\begin{array}{l}\text { 6. Total first marriage rates of } \\
\text { women }\end{array}$ & $\begin{array}{l}\text { Decline below } 0.8 \text { for a period of } \\
5 \text { years or more }\end{array}$ & - \\
\hline $\begin{array}{l}\text { 7. Proportion of non-marital } \\
\text { births }\end{array}$ & Higher than $10 \%$ & Higher than $25 \%$ \\
\hline 8. Total divorce rate & Exceeding 10\% & Exceeding $25 \%$ \\
\hline $\begin{array}{l}\text { 9. Proportion of women } \\
\text { cohabiting at age } 20-29\end{array}$ & Exceeding $10 \%$ & Exceeding $25 \%$ \\
\hline $\begin{array}{l}\text { 10. Proportion of never married } \\
\text { women aged } 20-29\end{array}$ & $\begin{array}{l}\text { Exceeding } 60 \% \text { among } 20-24 \\
\text { group for first time after } 1965\end{array}$ & $\begin{array}{l}\text { Exceeding } \\
\begin{array}{l}50 \% \\
\text { group }\end{array}\end{array}$ \\
\hline \multicolumn{3}{|l|}{ Contraceptive behaviour } \\
\hline $\begin{array}{l}\text { 11. Proportion of women aged } \\
15-44 \text { using the pill }\end{array}$ & Exceeding 20\% & - \\
\hline
\end{tabular}

For this purpose we use one of the three operationalisations of the Second Demographic Transition proposed by a group of three Czech demographers (Sobotka et al. 2003), who carefully analysed the status of art of their origin country within the framework of the above-mentioned theory. The simplest view, which we adopt in this study, perceives the 
Second Demographic Transition as a label for interconnected demographic changes. We pay attention to the timing when particular levels of selected indicators were reached and the relative change of some indicators, in time.

The first set of indicators, summarized in Table 3.1, is related to the period fertility level, which is expected to decline in the initial phase of the transition. A further distinction is made between fertility of young women aged below age 25, which is supposed to decline continuously, and fertility of women over age 30 , which is expected to recuperate in a later phase. The second set of indicators captures the postponement of marriage and childbearing. In the latter phase, we expect that the mean age of women at first marriage would become higher than at first birth due to the earlier timing of non-marital births and an increasing number of women entering marriage after experiencing first birth. The third set of indicators pertains to the decline of marriage as an institution and the rise of cohabitation and being single. Finally, the last indicator captures the spread of the contraceptive pill which, in theory, should be a precondition of the above-mentioned behavioural changes, but which could not be true in the Romanian case since it was banned during communist times, and only after the political system's fall did the information and the product enter and spread throughout the country. Instead, abortion was widely used for regulating birth, even if illegally during the prohibition period (19671989); so we jointly deal with indicators related to abortion numbers as well.

We use statistics from the international database Recent Demographic Developments in Europe, 2004 edition, because there are similar indicators available for all European countries and for extensive periods of time. Three other countries were selected to compare the pace of the changes. Two of them, Bulgaria and Hungary, are neighbouring countries to Romania, and have similar socio-political backgrounds, i.e. they all had, during the last decades, two totally different socio-economic and political contexts, and they all lived a rapid shift from a totalitarian regime to a liberal one starting in 1989. The shift profoundly marked the demographic behaviour and rapid transformations took place, since they were ideationally prepared for the socialist regime, but only after the political transition could the transformations freely manifest. We have chosen the Netherlands as a third benchmark country, since in this country the shift in values, 
attitudes, and in demographic behaviour, inspired the authors in developing the concept of the Second Demographic Transition (Lesthaeghe and Van de Kaa 1986; Van de Kaa 1987). Our latter choice was also chosen by Sobotka and his colleagues (Sobotka et al. 2003) in analysing the Czech Republic case.

\section{Period fertility level: long-lasting low fertility, early childbearing under question but no late type fertility}

The drop in fertility level towards values well below those necessary for simple replacement of the population is one of the very first phenomena observed in European countries. The criterion of TFR under the value of 1.8 births per woman for at least 5 years was fulfilled in Romania in 1991 (Figure 3.1a), lagging the Netherlands by 22 years. Similar lags are present in Bulgaria and Hungary, but a major difference in the evolution of this indicator between the three former socialist countries and the Netherlands is that the former countries did not experience a large baby-boom after the Second World War, as did the latter. The decrease manifested during the 1960s, reaching values under 2 births per woman for the first time in the world (in Hungary and Romania), a decade earlier than in the Netherlands. Only the pro-natalist policies implemented by the socialist governments could change the situation for a while, and the most successful programme was the declared-demographic-aimed Romanian policy. Yet there was nothing that could be done to change the individuals' reproductive behaviour after the 1989 transitions. 
Figure 3.1a. Total fertility rates

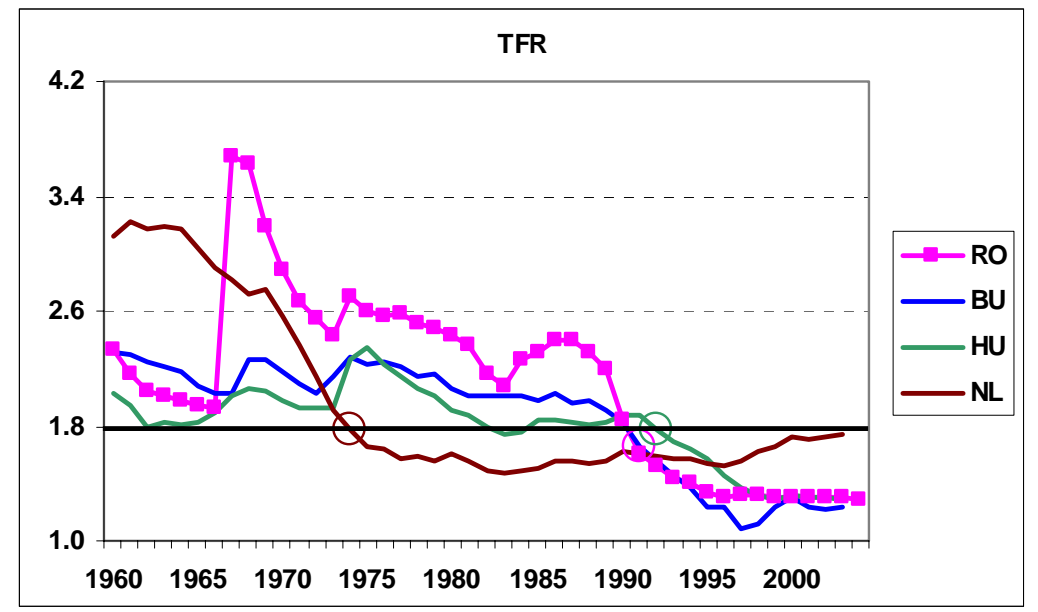

Notes. The horizontal line is related to the onset of first phase of the Second Demographic Transition, as referred to in Table 3.1. Circles mean onset of first phase.

Figure 3.1b. Total fertility rate of women below age 25

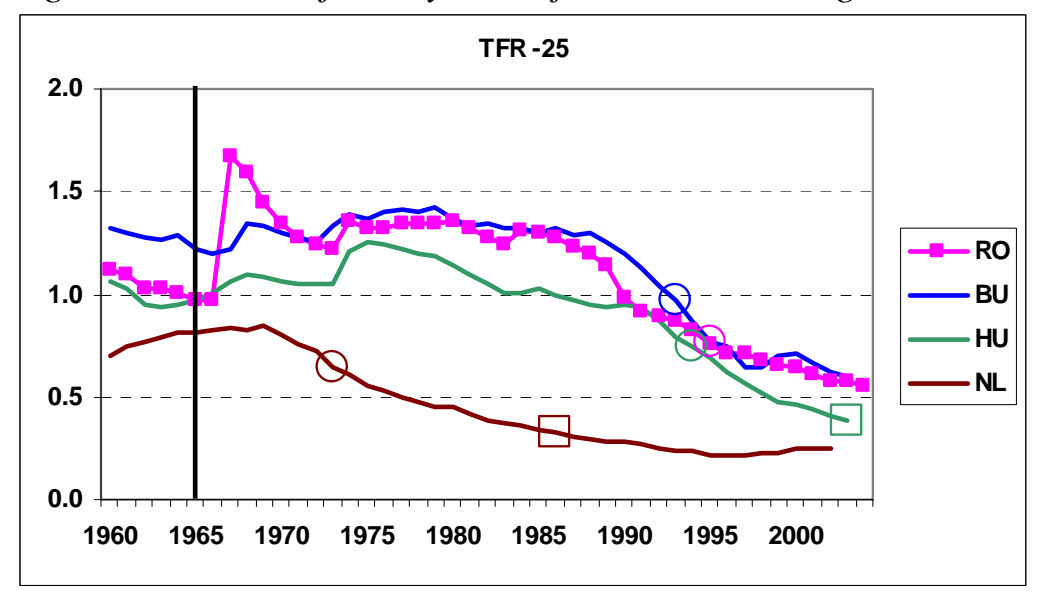

Notes. The vertical line is related to the onset of different phases of the Second Demographic Transition, as referred to in Table 3.1. Circles mean onset of first phase, squares mean onset of second phase.

Figure 3.1c. Total fertility rate of women beyond age 30

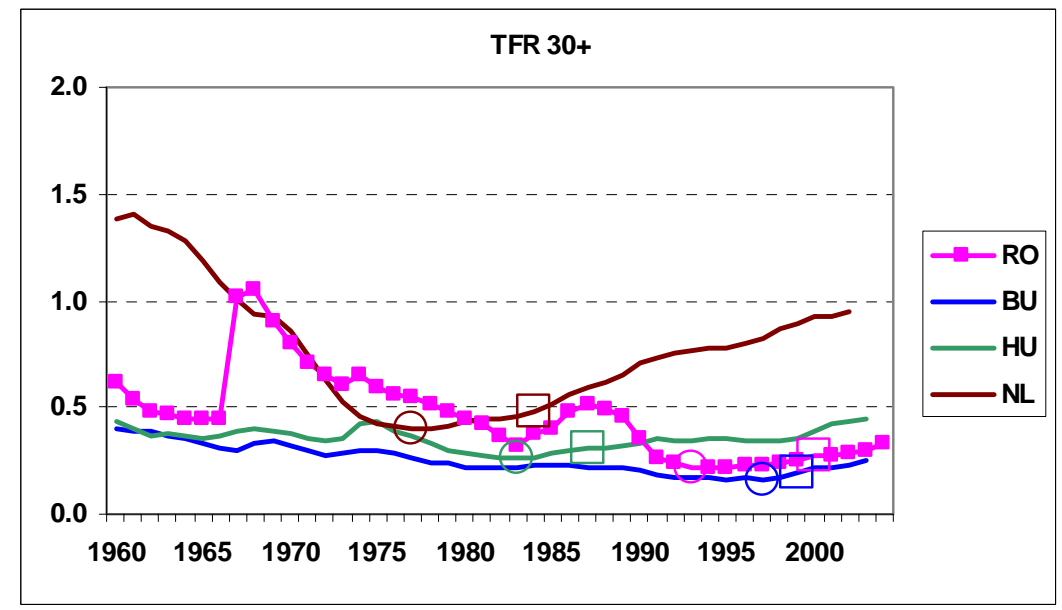

Note: Circles mean onset of first phase, squares mean onset of second phase. 
The contribution of women younger than 25 years of age to the TFR declined by $20 \%$ relative to the level reached in 1965 in the post-socialist countries, again only after 1990 (1995 in Romania), lagging the Netherlands by a quarter of a century (Figure 3.1b). A further decline (by 60\%), necessary for reaching the second stage of the demographic transition, was not yet observed, neither in Romania nor in Bulgaria, while Hungary reached this level only very recently. The early childbearing pattern is under question, now that we expect a further decline in young Romanian women's fertility.

Instead, the contribution to the TFR of women older than 30 years of age (see Figure 3.1c) had an upturn level (observed since 1965) in all four countries. The lowest value for Romanian women was reached in 1993 and it was 0.22 births per woman. All analysed countries started to increase fertility beyond age 30 after a minimum attained, overtaking the lowest level observed after 1965 by at least $20 \%$. The three post-socialist countries are lagging the Netherlands by 7-20 years, the earliest being Hungary and the latest Bulgaria. Even if they fulfill the corresponding criteria for entering the second stage of the demographic transition, none of them manifested so firm an increase in their late fertility as the Dutch women did. Late childbearing is still not common in Romania.

\section{Postponement of childbearing and marriage: better unmarried than childless}

The postponement of childbearing and marriage are, perhaps, the main manifestation of the Second Demographic Transition. It can be observed clearly in the three post-socialist neighbour countries (Figures 3.2a-c).

Romania was the last country that started a lasting increase of age at first birth: every year since 1996, the mean age at first birth has increased by 0.1-0.3 years. Bulgaria began the process earlier by 4 years and Hungary by 6 years, but they all lagged the Netherlands by about two decades (Figure 3.2a), and all reached a delayed entry into motherhood by at least 2 years in a very short period of time.

If the first birth occurs within, or out of the frame of a marriage is another question, since the increase of the mean age at first marriage paralleled the former trend, in general, more 
rapidly (Figure 3.2b). First Bulgaria (1994), and very recently Romania (2004), attained the status where mean age at first birth is lower than mean age at first marriage (Figure 3.2c). Neither Hungary nor the Netherlands have entered in this stage (until 2003), qualified as signs of the second phase of the Second Demographic Transition, and they are known as more advanced in the process. A possible explanation is the bigger resistance to changes of the first birth pattern than resistance to changes of a marriage pattern. It is possible that Romanian and Bulgarian women accept easier alternatives to marriage than a change to their preference for early childbearing.

Figure 3.2a. Mean age of women at first birth

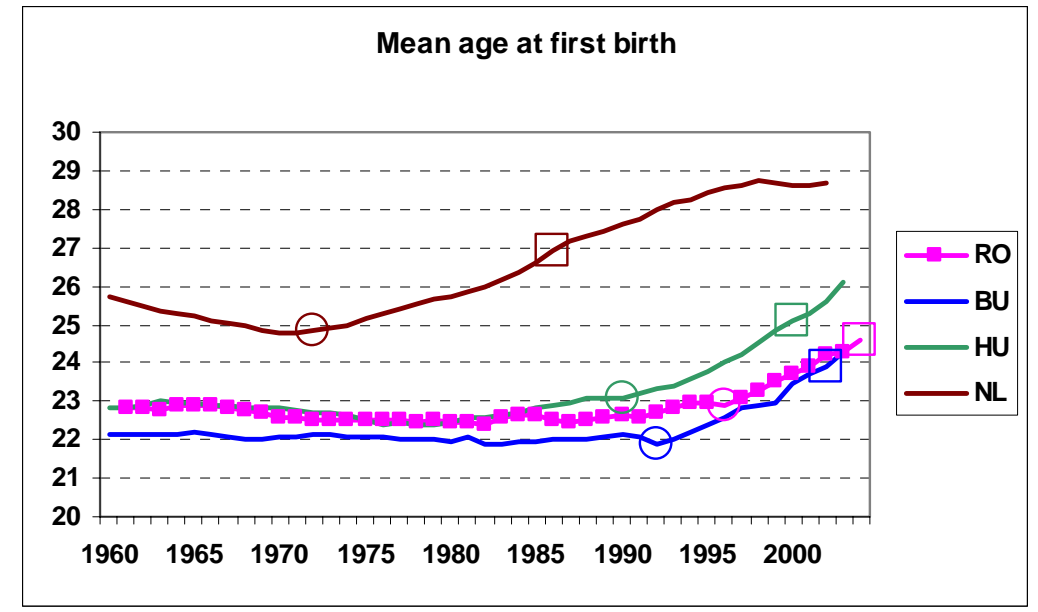

Note: Circles mean onset of first phase, squares mean onset of second phase.

Figure 3.2b. Mean age of women at first marriage

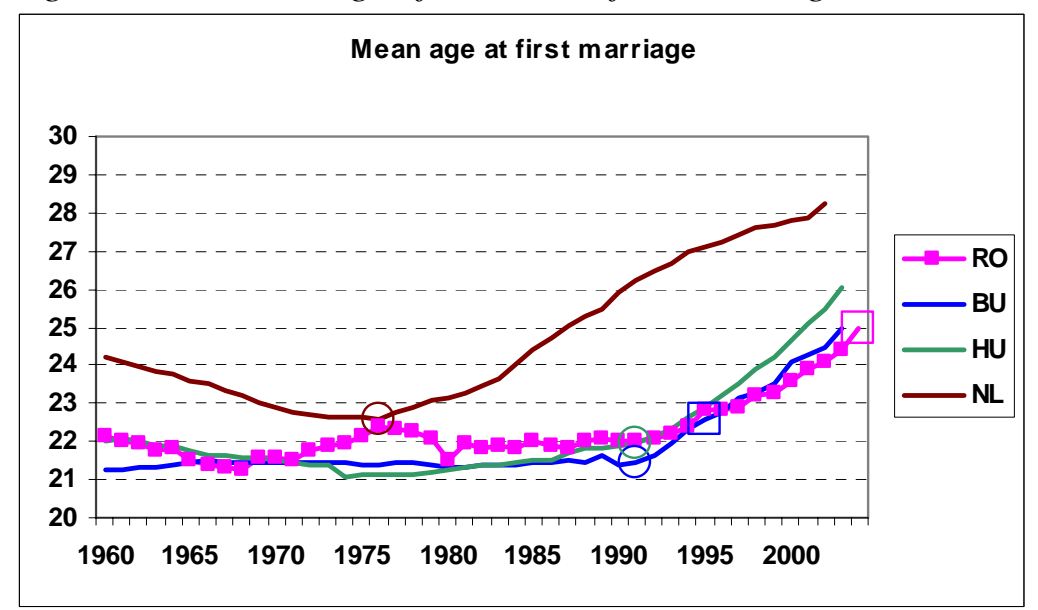

Note: Circles mean onset of first phase, squares mean onset of second phase. 
Figure 3.2c. Difference between mean age at first birth and first marriage

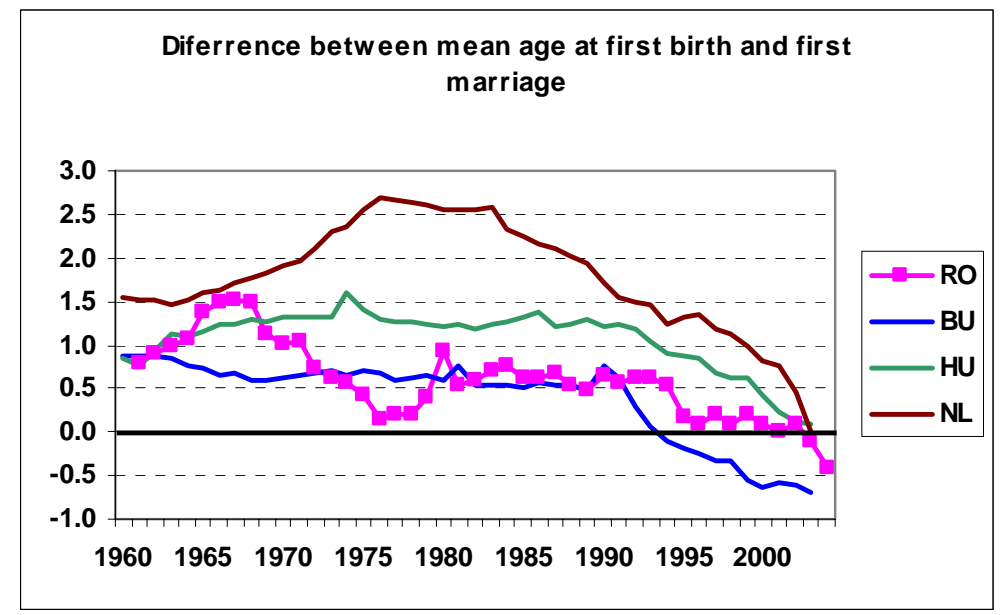

\section{Weakening of marriage as an institution: marriage rates dropped, but the stability of marriages did not change}

Almost all the indicators from the category of the weakened marriage institution (proportion of non-marital birth, total first marriage rate, and total divorce rate) show that it is continuously progressing.

The proportion of non-marital births (Figure 3.3a) rose dramatically immediately after the political change in Romania, Bulgaria, and Hungary, overtaking the level of $25 \%$ first in Bulgaria (in 1995), then in Hungary (in 1998) and last in Romania (in 2000). Interestingly, no lag to the Netherlands was observed in respect to this indicator, and moreover Bulgaria had advanced the trend since $10 \%$ of all births were traditionally out of wedlock since 1966. Sobotka (2003) showed that in Bulgaria extra-marital births have increasingly occurred to lone mothers, while in Romania cohabiting couples have increasingly accepted birth out of wedlock.

The level of marriage, expressed by the total first marriage rate (see Figure 3.3b), show indeed the onset of the decrease of the popularity of marriage, even if in the Romanian case, it is not so pronounced and started a little bit later than in its neighbour countries. The threshold of 0.8 first marriages per woman was attained only in 1993 in Romania, while in Bulgaria this occurred in 1991, in Hungary in 1987 and in the Netherlands in 1976. In Romania, the lowest level, reached in 2001, was above 0.6, while in the other three countries this indicator dropped even farther. 
Together with a decreasing popularity of marriage one could expect an increasing spread of other forms of unions. Information about cohabiting couples was registered for the first time only at the last census (2002), from where we learn that the proportion of women cohabiting at age 20-29 has been $8.5 \%$. Romania is not fulfilling the $9^{\text {th }}$ criterion in the list of indicators of the onset of the Second Demographic Transition, since more than $10 \%$ of cohabitations at the above-mentioned age were expected (Table 3.1). Moreover, the $10^{\text {th }}$ indicator is also not fulfilled. The proportion of never married women aged $20-24$ is above $40 \%$ in 2002 and this is far from the $60 \%$ required by the scheme. Despite the significant increase of the mean age at first marriage (Figure 3.2b), the marriage pattern can be still characterized as early.

Divorce also should have contributed to the weakening marriage pattern. In the Second Demographic Transition schedule the threshold for total divorce rate has been fixed at $10 \%$. But in Romania, such a level of divorce had been the rule already in the 1960s. The peculiarity of divorce in Romania is that its level did not change significantly up to now (with the exception of the period 1967-1974 when the divorce legislation made it almost impossible to afford a divorce), while in the other countries, especially the Netherlands and Hungary, the total divorce rate has had an upward trend.

Figure 3.3a. Proportion of non-marital birth

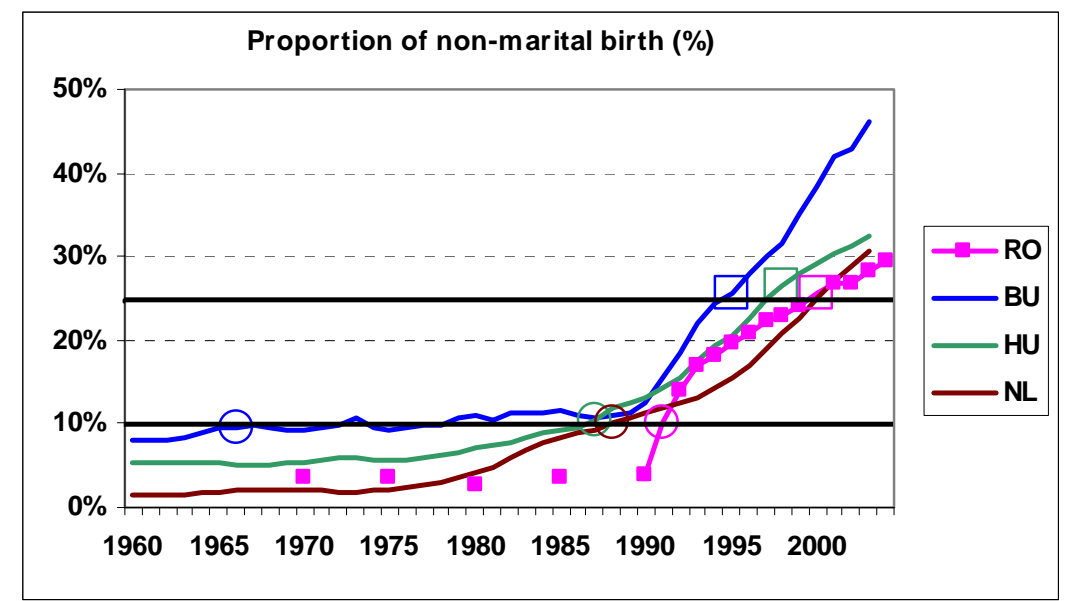

Notes. The horizontal lines are related to the onset of different phases of the Second Demographic Transition, as referred to in Table 3.1. Circles mean onset of first phase, squares mean onset of second phase. 
Figure 3.3b. Total first marriage rate

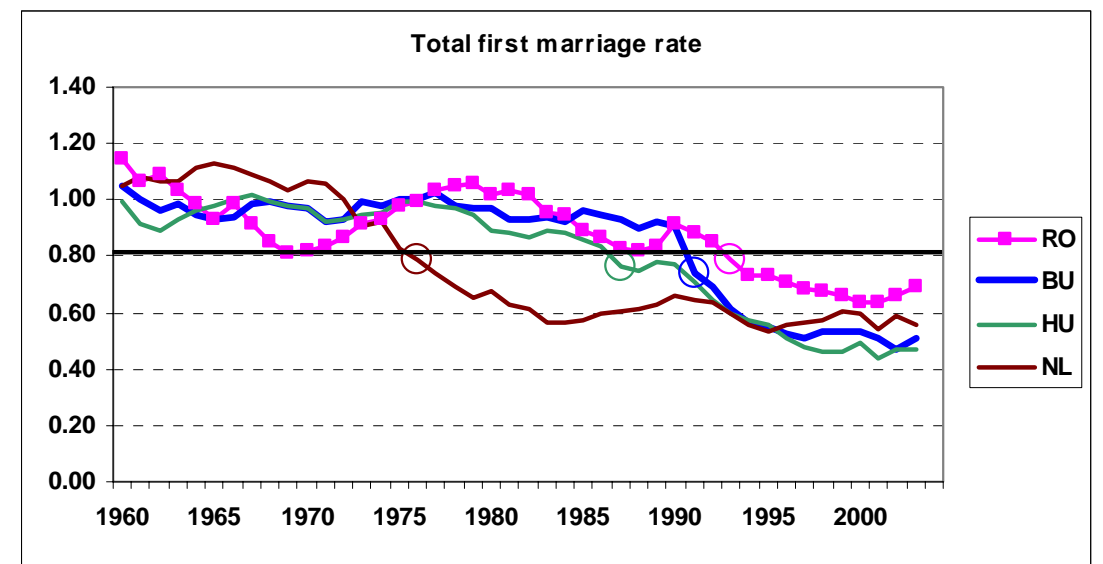

Note. The horizontal line is related to the onset of the first phase of the Second Demographic Transition, as referred to in Table 3.1. Circles mean onset of first phase, squares mean onset of second phase.

\section{Figure 3.3c.Total divorce rate}

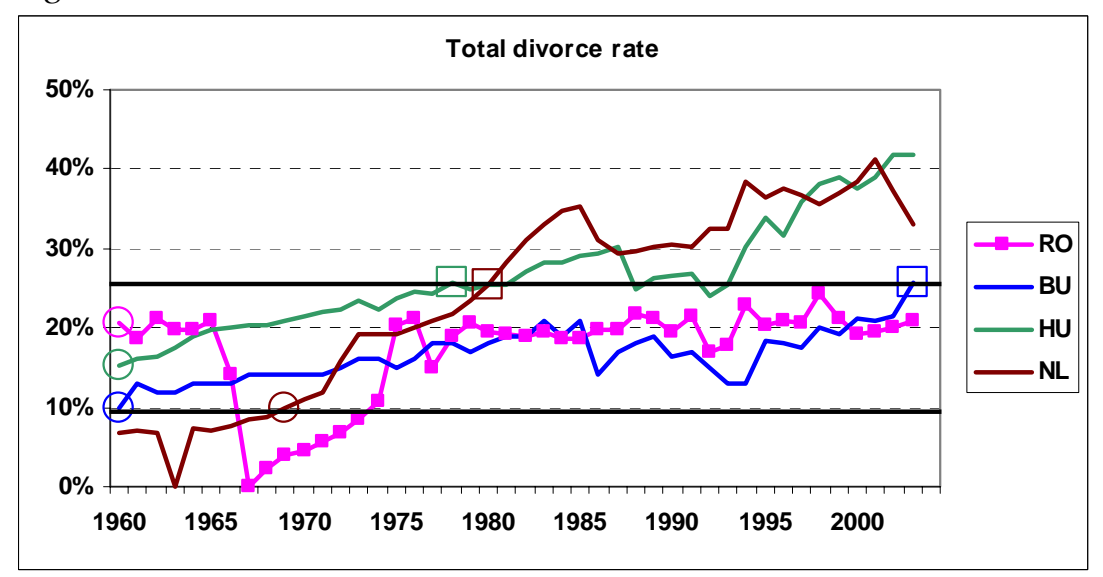

Notes. The horizontal lines are related to the onset of different phases of the Second Demographic Transition, as referred to in Table 3.1. Circles mean onset of first phase, squares mean onset of second phase.

\section{Contraceptive behaviour}

The last indicator on the Second Demographic Transition scheme is also the third criteria not fulfilled by Romania. Only $17.5 \%$ of women aged $15-44$, instead of at least the $20 \%$ required, were using the pill, according to GGS 2005. 
Figure 3.4. Abortion rate, per live-birth

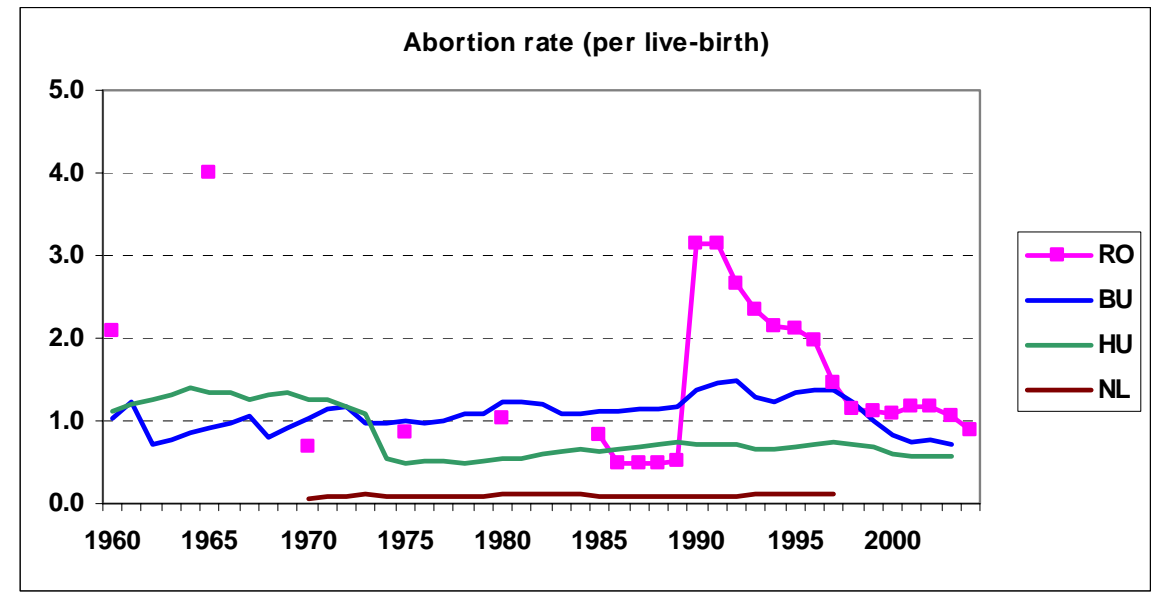

But the comparison with the Netherlands as benchmark, in terms of this criterion, is not appropriate because contrary to western societies, where modern contraception has steadily risen since the late 1960s, in Romania the early legalization of abortion, in 1957 (modern contraception was not known at that time) durably affected birth-control behaviour of women. Romanian women have intensively used abortion as a birth control method, and not particularly at the beginning of reproductive-life as in other societies where it is used only in case of contraceptive failure, but rather for limiting the number of their offspring in accordance to the desired family size (Mureşan 2006). Even illegally (1967-1989), abortion was widely used as birth control, since family planning methods were forbidden and mainly unknown until 1990. Abortion rates were particularly high in the years close to the ban period, when it was the sole method of family planning. Step by step, after 1990, abortion has been replaced by contraceptives, but the usage of the latter is still far from the level usually found in western societies.

\section{Early stage of the Second Demographic Transition in Romania}

In total eight out of eleven "threshold levels" were reached in the period 1991-1996, so the onset of the transition in Romania can be judged to be very recent, belonging to the first half of the 1990s, and lagging the Netherlands by twenty to twenty-two years.

Analysing the issue from the point of view of ideational changes, which according to the theory go hand in hand with demographic developments, Rotariu (2006) has shown that this is not (yet) the case of Romania, despite the clear drop in fertility and marriage rates 
and significant postponement in the timing of the two phenomena. His finding indicates that the demographic change does not follow from changes in the value system surrounding the family and relationships among its member, nor is it necessarily associated with other behavioural changes such as higher levels of cohabitation, increasing divorce rates and higher instances of single motherhood. The "bourgeois family," which centres on the child, is still the dominant one.

Can we observe changes in the living arrangements and life transitions among young Romanians and identify the expected de-standardisation of the life course? The 2005 survey (GGS) makes possible the investigation of life transitions for a broad period of time. We have settled on two contrasting periods: 1980-1989, for the time before the societal transition, and 1996-2005, the most recent ten years. We have omitted the fiveyear period between 1990 and 1995, for the sake of a better contrast between the former demographic regime and the rapidly changing recent one, since immediately after the political change, demographic behaviour could have been affected by the euphoria of achieving freedom, following a half century of authoritative regime. Another advantage in using ten-year periods instead of five-year periods is the increasing statistical significance and shortening confidence interval of our estimates. However, in our crosscountries comparisons we also make use of indicators from the period 1990-1994, since one of our aims is to see similarities and differences with Bulgaria and Hungary, two neighbour countries with which Romania sometimes had shared history.

While the effect of the societal change can be contrasted by analysing life-table indicators of the above-mentioned synthetic cohorts, a birth cohort perspective can better stress the behavioural changes. We have supplemented the analysis by four distinctive real cohorts: 1950-1959, 1960-1969, 1970-1974 and 1975-1979. Those belonging to the first cohort started their own family life entirely during the communist times; those from the second cohort have lived their $20^{\text {th }}$ year of age close to the years of the political change, either before or after the turbulences from 1989; the last two younger cohorts entered their adulthood in post-socialist times. Instead of a single birth cohort for those born during the 1970s, we preferred to separate them into two, five-year cohorts, even if the last one is not older than 26-30 at the time of interview, because, as we have seen above, the 
demographic changes were accelerated during the transition and we expect even more changes in the youngest cohort.

\section{Separating from the parental family}

Leaving the parental home is the first event treated by the demographic literature when transition to adulthood is under study. Usually, the focus is on the physical separation of young men / women from the parental home, by moving to another dwelling. This moment is considered to be the onset of an independent life, when the parental care is weakening and adulthood begins. If this is the case in west European countries, in the east European ones it often happens that a new formed union starts a more or less autonomic life in the parental home, forming multi-nuclear families that are used to sharing the same dwelling. Leaving the parental home occurs later, when the young pair can afford their own apartment or house, or does not occur at all, since in the countryside there is a practice that one of the children (married or not) remains in the parental house and takes care of parents in their old age. Entering adulthood could thus happen without leaving the parental home, and we have to consider this event in connection with union formation. Separation from the parental family was first considered by Philipov and Jasilioniene (2007). They constructed adequate life-tables for Bulgaria and Russia, and we have done the same for Romania.

\section{Leaving the parental home}

At the beginning of the 1990 's, men / women from central eastern European countries were leaving the parental home later than those from other European countries, with the well-known exception of Italy and Spain (Phillipov and Jasilioniene 2007). Our data shows (Table 4.1 ) that at age $30,71 \%$ of men and $89 \%$ of Romanian women have left the parental home. The level is in between the levels observed for Hungarian and Bulgarian men, and it is higher by $3 \%-9 \%$ for Romanian women than for the women from the other two countries. 
Table 4.1 Cumulative percent ever leaving the parental home by age 30 and 40, by countries

\begin{tabular}{cccc}
\hline & $\begin{array}{c}\text { Romania } \\
\mathbf{1 9 9 0 - 1 9 9 4}\end{array}$ & $\begin{array}{c}\text { Bulgaria } \\
\mathbf{1 9 9 0 - 1 9 9 4}\end{array}$ & $\begin{array}{c}\text { Hungary } \\
\mathbf{1 9 8 8 - 1 9 9 3}\end{array}$ \\
\hline At age 30 & & & \\
men & 71 & 74 & 65 \\
women & 89 & 86 & 80 \\
At age 40 & & & 75 \\
men & 83 & 83 & 84 \\
women & 94 & 94 & 25 \\
Mean age: (at transition, conditional on transition before age 40) & 23 & 22 \\
men & 23 & 21 & 21 \\
women & 21 &
\end{tabular}

Sources: for Bulgaria, Philipov and Jasilioniene (2007); for Hungary, Andersson and Philipov (2002)

At age 40 the difference between Romanian and Bulgarian men and women disappears: almost all women of the synthetical cohort 1990-1994, left the parental home (94\%) and a very high percentage (84\%) of men did the same. In Hungary both sexes left their parents' home in a smaller percentage, by $10 \%$, despite the general assessment that Hungarians are more advanced in historical demographic changes. Hungarian men leave the home around the mean age of 25 , i.e. three years later than their female co-nationals, and two years later than the same sex Romanians or Bulgarians. Women forego men in leaving the parental home by two years, in both Romania and in Bulgaria.

What is interesting to observe is that the changes from one period to the other are not in the direction suggested by the Second Demographic Transition Theory. The youth are not independents in a greater percentage nor earlier in life, since the cumulative percentage ever leaving the parental home decreased at every age (Table 4.2). During the 1980s, $86 \%$ of men and $95 \%$ of women left the parental home by the exact age 40 , then there were only $81 \%$ men and $91 \%$ women who did so during the late 1990 s and early 2000 s. Half of the men who left the parental home during the socialist times were under age 24, while during the times of market-oriented economy, they succeeded in the same proportion only at age 26 . Women generally leave the home earlier than men, as Table 4.2 shows, and this suggests that leaving home must be related mainly to union formation (where the women are younger than the men) and not to other causes such as following studies in other localities (where women and men have the same age), or to enrolment in military services (where men go early, but women do not go at all). The same two-year 
postponement was observed from one period to the other among women as well, suggesting increasing difficulty in affording a separate home.

Table 4.2. Cumulative percent ever leaving the parental home

\begin{tabular}{|c|c|c|c|c|}
\hline Age & $\begin{array}{c}\text { Men } \\
1980-1989 \\
\end{array}$ & $\begin{array}{c}\text { Men } \\
1996-2005\end{array}$ & $\begin{array}{c}\text { Women } \\
1980-1989\end{array}$ & $\begin{array}{c}\text { Women } \\
1996-2005\end{array}$ \\
\hline 16 & 7 & 3 & 11 & 5 \\
\hline 18 & 13 & 5 & 26 & 15 \\
\hline 20 & 28 & 15 & 50 & 37 \\
\hline 22 & 38 & 26 & 69 & 52 \\
\hline 24 & 53 & 39 & 81 & 67 \\
\hline 25 & 59 & 45 & 84 & 73 \\
\hline 26 & 64 & 52 & 87 & 76 \\
\hline 28 & 73 & 60 & 91 & 83 \\
\hline 30 & 78 & 67 & 92 & 85 \\
\hline 35 & 83 & 76 & 95 & 90 \\
\hline 40 & 86 & 81 & 95 & 91 \\
\hline mean age: & 23 & 26 & 20 & 23 \\
\hline \multicolumn{5}{|c|}{ (at transition, conditional on transition before age 40 ) } \\
\hline 1st decile at age: & 17 & 19 & 16 & 17 \\
\hline 1st quartile at: & 20 & 22 & 18 & 19 \\
\hline median at age: & 24 & 26 & 20 & 22 \\
\hline 3rd quartile at: & 29 & 35 & 23 & 24 \\
\hline
\end{tabular}

Now we switch to the cohort perspective in order to see if real behavioral changes took place from one birth cohort to the other, or the period indicators are catching more temporary advancements or postponements in leaving the parental home, closely related to the societal situation when the time for leaving the parental home arrives.

Figure 4.1. Occurrence / exposure rates for leaving the parental home
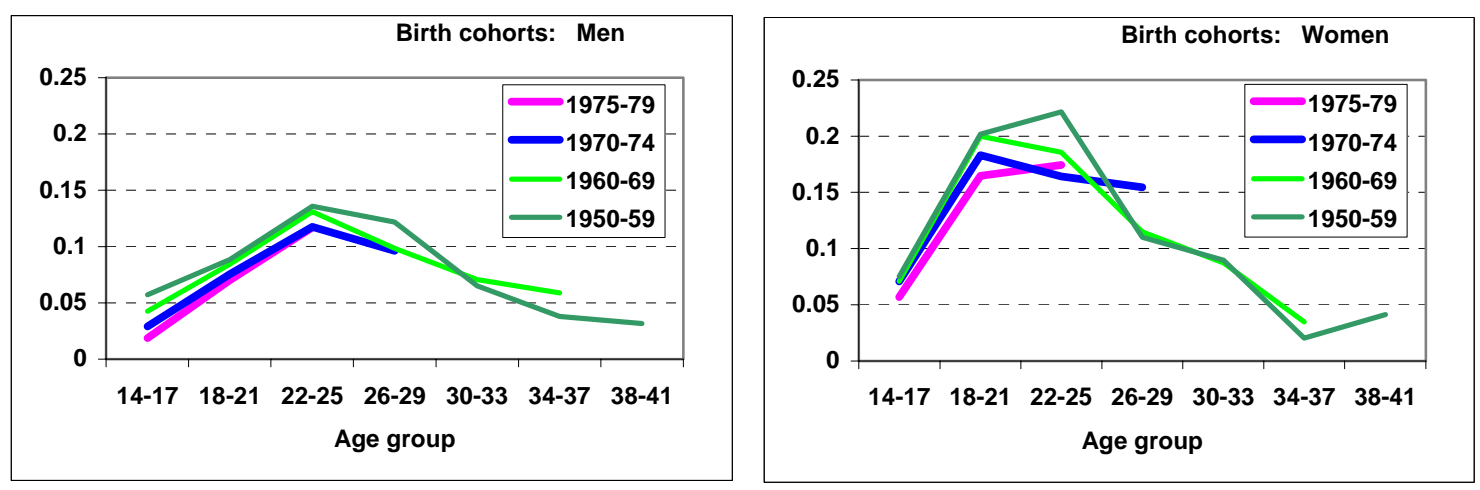
Figure 4.1 shows the occurrence / exposure rates by four age groups separately for men and women. We can observe that the risks of leaving home are higher for women than for men; that the highest risks for men are at ages 22-29, while for women at ages 18 to 25 , and the risks are lowering as the birth cohort is younger. All these findings have mostly been noted above, but what is new to observe in the graphs is the increase of women's risks to leave the parental home in later ages, as a recuperation of postponements during younger ages, in the birth cohorts of the 1970s. This development cannot be a sign of "modernisation", but at least it can be a sign that the young generations who could not afford their independent housing during their up-to-now typical young age, could afford it later. Both for men and for women the long-rank test for equality of the survival function for the ages of leaving home before 30 indicates that the four cohorts differ significantly.

\section{Separating from the parental family: before first union formation, at first union formation, or after union formation?}

Leaving the parental home, in Romania, depends mainly on the affordability of a dwelling. The reasons to move apart from the parents can be going to study in another locality if there is not an educational option matching the desires of the young in their place of residence, or going to the military service (for men), or for living together with a partner, or just the wish to achieve independence. The affordability of settling in a new dwelling increases in the case of marriage, since solidarity of relatives plays a role. If the young couple is married, and if they had a wedding celebration, they invest the gift money received from their guests in order to buy an apartment, i.e. advancement for a credit with a bank. Very often the parents of the bridegroom and the bride help them, to the extent they can, to afford such an investment. But in many cases the only solution for a new couple is to stay together at the parental home of one of them, usually of the man.

It is also usual for parents to carry the burden of living expenses for their children studying in another locality. This is especially the case after the historical turnover in 1989, when all subventions of the state vanished. However, unemployment appeared, and 
many parents could no longer support their children living apart for the sake of following studies.

Studying the separation from the parental family, more precisely leaving the parental home related to union formation, gives us a general view of the demographic consequences of the above-mentioned situation. We use a competing-risk approach, distinguishing between three situations of separation: i) either an individual leaves the parental home before forming a first union (it could be for studying, for partaking compulsory military service, to avoid parental control, or for any other reason than union formation; but we do not know this from the information gathered in GGS), ii) either he/she leaves the parental home at the start of a union, or iii) the new couple starts the union while living in the parents' home. We allow for a difference of one month between the two events in the second risk.

Table 4.3: Cumulated percent leaving the parental home before first union, competing-risks leaving home with first union or first union before leaving home

\begin{tabular}{lcccc}
\hline Age & $\begin{array}{c}\text { Men } \\
\mathbf{1 9 8 0 - 1 9 8 9}\end{array}$ & $\begin{array}{c}\text { Men } \\
\mathbf{1 9 9 6 - 2 0 0 5}\end{array}$ & $\begin{array}{c}\text { Women } \\
\mathbf{1 9 8 0 - 1 9 8 9}\end{array}$ & $\begin{array}{c}\text { Women } \\
\mathbf{1 9 9 6 - 2 0 0 5}\end{array}$ \\
\hline 16 & 6 & 3 & 9 & 3 \\
18 & 12 & 4 & 14 & 6 \\
20 & 24 & 12 & 22 & 13 \\
22 & 29 & 19 & 24 & 16 \\
24 & 32 & 22 & 25 & 18 \\
25 & 34 & 24 & 25 & 19 \\
26 & 35 & 26 & 25 & 20 \\
28 & 36 & 27 & 26 & 21 \\
30 & 37 & 30 & 27 & 22 \\
35 & 37 & 32 & 27 & 22 \\
40 & 38 & 33 & - & 21 \\
& & & & \\
mean age: & 20 & 23 & 18 & 19 \\
(at transition, conditional & on transition before age 40$)$ & & - \\
1st decile at age: & 17 & 19 & 16 & - \\
1st quartile at: & 20 & 26 & 24 & \\
median at age: & - & - & - & \\
3rd quartile at: & - & - & & \\
\hline
\end{tabular}


Indeed, as we expected, the ultimate level of leaving home before first union, measured here by the cumulative percentage at exact age 40 , dropped by $5 \%$ from one period to the other, both in the case of men and for women (Table 4.3). The drop is more drastic at the younger ages when parents are supposed to support their children. For example, at exact age 25 , only $24 \%$ of men and $19 \%$ of women would leave their parental home between 1996 and 2006, while 15 years earlier, $34 \%$ of men and $25 \%$ of women were leaving their parental home. The mean age at leaving home for reasons not related to union formation increased by 3 years, but the postponement is greater among the younger ages. For example, the indicator for the first quartile shows an increase of 6 years of age at which time a quarter of men left the parental home, and in the case of women, the same indicator shows that while during the 1980s a quarter of women left the home before age 24. During the period 1996-2006 less then a quarter of women left the parental home before age 40 , for reasons not related to union formation. In Bulgaria, contrary to Romania (Philipov and Jasilioniene 2007), the figures show an increase both of the ultimate level and of the mean age of leaving home for reasons other than union formation. We have no comparable data for Hungary.

Leaving home to form a union (regardless if it is a marriage or a consensual union) is also different in Romania, as compared to the Bulgarian case. Very few Bulgarian men (about $11 \%$, i.e., three times less than Romanian men) and fewer Bulgarian women (about $40 \%$, i.e., two-thirds of the share of Romanian women) leave the parental home simultaneous with entering in a union. Despite the difference in the level, the mean ages at transition are similar with Romanians.

The changes from one period to the other are not so contrasting, in Romania, as in the case of the first risk (Table 4.4). We only observe a slight decrease of the ultimate level for the men (from $34 \%$ to $31 \%$ ) and a smaller increase for women (from $59 \%$ to $60 \%$ ). The mean age at leaving home simultaneously with entering in a first union, increased only by one year. Men's age-pattern changed more than the women's age-pattern; the former postponed nest leaving more than women. (See the $1^{\text {st }}$ decile and the $1^{\text {st }}$ quartile in Table 4.4). 
Table 4.4: Cumulated percent leaving the parental home with first union, competing-risks leaving home before first union or first union before leaving home

\begin{tabular}{lcccc}
\hline Age & $\begin{array}{c}\text { Men } \\
\mathbf{1 9 8 0 - 1 9 8 9}\end{array}$ & $\begin{array}{c}\text { Men } \\
\mathbf{1 9 9 6 - 2 0 0 5}\end{array}$ & $\begin{array}{c}\text { Women } \\
\mathbf{1 9 8 0 - 1 9 8 9}\end{array}$ & $\begin{array}{c}\text { Women } \\
\mathbf{1 9 9 6 - 2 0 0 5}\end{array}$ \\
\hline & & & & \\
16 & 0 & 0 & 2 & 1 \\
18 & 1 & 0 & 10 & 9 \\
20 & 3 & 2 & 26 & 22 \\
22 & 7 & 5 & 40 & 33 \\
24 & 16 & 13 & 50 & 43 \\
25 & 20 & 16 & 52 & 47 \\
26 & 23 & 20 & 54 & 50 \\
28 & 29 & 23 & 57 & 56 \\
30 & 32 & 27 & 57 & 57 \\
35 & 34 & 30 & 58 & 60 \\
40 & 34 & 31 & 59 & 60 \\
& & & & \\
mean age: & 24 & 25 & 21 & 22 \\
(at transition, conditional & on transition before age & & & \\
1st decile at age: & 22 & 23 & 18 & 18 \\
1st quartile at: & 26 & 29 & 20 & 20 \\
median at age: & - & - & 24 & 26 \\
3rd quartile at: & - & - & - & - \\
\hline
\end{tabular}

The last of the three competing risks in the phenomenon of separation from the parental family fills in the general view about how youth become independent (Table 4.5). Forming the first union before leaving the parental home is, in fact, the most unpopular way, during both periods of time, and both genders. The same is true for Bulgarian women but not for Bulgarian men, since usually in Bulgaria the woman goes to the man's parental home when they form a union ${ }^{4}$. Yet there are, definitely, fewer couples in Romania than in Bulgaria who remain in the house of their parents.

However, in Romania, the ultimate level of forming a union in the parental home of men increased from $23 \%$ to $28 \%$ from one period to the other, while in Bulgaria it declined from $40 \%$ to $26 \%$ - so a convergence occurred. In both countries the mean age increased by one year for men, keeping the age gap between the two countries unchanged. Romanian men are in general older by one year than Bulgarian men at the transition time (25 years old and 24 years old, respectively, around the year 2000).

\footnotetext{
${ }^{4}$ data for Bulgaria are not shown here; they are published in (Philipov and Jasilioniene, 2007), Table 4.3
} 
Women's situation is quite different. Twice less Romanian women remain in their parental home than Bulgarian women when they enter in a first union, and unlike for men, no convergence occurred. Only 13\%-14\% of separations from the parental home are made in such a way among Romanian women. The similarity with Bulgarian women is where it concerns the mean age: it increased by two years, from 21 to 23 , between the two periods of socialist times and post-socialist times, respectively.

Table 4.5: Cumulated percent first union before leaving the parental home, competing-risks leaving home before first union or with first union

\begin{tabular}{|c|c|c|c|c|}
\hline Age & $\begin{array}{c}\text { Men } \\
1980-1989 \\
\end{array}$ & $\begin{array}{c}\text { Men } \\
\text { 1996-2005 } \\
\end{array}$ & $\begin{array}{c}\text { Women } \\
1980-1989 \\
\end{array}$ & $\begin{array}{c}\text { Women } \\
\text { 1996-2005 } \\
\end{array}$ \\
\hline 16 & 0 & 0 & 0 & 1 \\
\hline 18 & 1 & 0 & 2 & 2 \\
\hline 20 & 2 & 2 & 6 & 4 \\
\hline 22 & 5 & 7 & 8 & 7 \\
\hline 24 & 13 & 12 & 11 & 10 \\
\hline 25 & 15 & 15 & 11 & 11 \\
\hline 26 & 17 & 17 & 12 & 11 \\
\hline 28 & 19 & 21 & 12 & 12 \\
\hline 30 & 20 & 24 & 13 & 13 \\
\hline 35 & 23 & 27 & 13 & 14 \\
\hline 40 & 23 & 28 & 13 & - \\
\hline mean age: & 24 & 25 & 21 & 23 \\
\hline \multicolumn{5}{|c|}{ (at transition, conditional on transition before age 40 ) } \\
\hline 1st decile at age: & 23 & 23 & 23 & 24 \\
\hline 1st quartile at: & - & 31 & - & \\
\hline median at age: & - & - & - & - \\
\hline 3rd quartile at: & - & - & - & - \\
\hline
\end{tabular}

All risks taken together describe the overall process of separation from the parental family. We added all three risks described above, correspondingly for each exact age and we obtained Table 4.6 (top half). We may do so because we used a multi-decrement competing-risk approach, which guarantees the decomposition of an overall event by means of an alternate way (usually called causes or risks) of achieving it.

Since the ultimate level of separating from the parental family is above $90 \%$, we can conclude that it was and it still remains universal in Romania, regardless of gender. What has changed over the two periods is the age-pattern of separation, and remotely, the way 
of achieving it. Men postponed their separation by three years on average, while women postponed it by two years, increasing the gender gap from two years during 1980-1989, to three years during 1996-2005.

Table 4.6: Cumulated percent leaving the parental home connected with first union

\begin{tabular}{|c|c|c|c|c|}
\hline Age & $\begin{array}{c}\text { Men } \\
1980-1989\end{array}$ & $\begin{array}{c}\text { Men } \\
1996-2005\end{array}$ & $\begin{array}{c}\text { Women } \\
1980-1989\end{array}$ & $\begin{array}{c}\text { Women } \\
1996-2005\end{array}$ \\
\hline 16 & 7 & 3 & 12 & 6 \\
\hline 18 & 14 & 5 & 28 & 17 \\
\hline 20 & 30 & 17 & 54 & 40 \\
\hline 22 & 42 & 31 & 74 & 56 \\
\hline 24 & 62 & 48 & 85 & 71 \\
\hline 25 & 70 & 56 & 89 & 78 \\
\hline 26 & 75 & 63 & 92 & 81 \\
\hline 28 & 84 & 72 & 96 & 88 \\
\hline 30 & 89 & 81 & 97 & 91 \\
\hline 35 & 94 & 89 & 98 & 95 \\
\hline 40 & 96 & 91 & 99 & 96 \\
\hline mean age: & 22 & 25 & 20 & 22 \\
\hline \multicolumn{5}{|c|}{ (at transition, conditional on transition before age 40 ) } \\
\hline 1st decile at age: & 17 & 19 & 16 & 17 \\
\hline 1st quartile at: & 20 & 21 & 18 & 19 \\
\hline median at age: & 23 & 24 & 20 & 21 \\
\hline 3rd quartile at: & 26 & 29 & 22 & 25 \\
\hline
\end{tabular}

The way of separating from the parental family was different between men and women and it does not change when we compare men with women: men use almost equally all the three ways connected to union formation, while women mostly prefer to leave the parental home when they form a first union, and they least prefer to form a union in their own parental home. When we compare the three ways separately for men and women, we observe some changes. In more recent times, less (by 5\%) men leave the parental home for reasons not related to union formation, as compared to older times. In the meantime, however, there is a shift, where more (by 5\%) men form unions at the home of their parents, compared to the same category in previous times. In the case of women we also observed a reduction of leaving the parental home before forming a union. All the changes could be explained by the increased difficulty to afford a single separate-fromparents dwelling, connected with an increased economic difficulty of families and less support from the state in housing policies. 


\section{Forming a first union}

Marriage is traditionally universal and early, and only recently (early 1990s) has it begun to weaken and to be postponed, as is documented in the inland literature (Mureşan and Rotariu 2000; Mureşan et al. 2007), as we (partly) documented earlier in chapter 3. The question is to what extent non-marital unions developed to fill the gap remaining after the level of marriage decreased. In the following we analyse marriage and union formation, first separately by single decrement life-tables, and afterwards we study marital and nonmarital unions simultaneously using the competing-risks life-table method. We concentrate only on first unions, either marriages or cohabitations, because the number of repeated unions is very small.

\section{First marriage: single decrement perspective}

The annual total first marriage rate (TFMR) fell in the 1990s to the threshold of 0.8 marriages per women in all the three central eastern European countries under study. However, given that all three countries experienced a significant postponement during this period, the TFMR was affected by the changing age structure of marriages and reflects more the postponement than the fall in the level of nuptiality. A better indicator of the level of first marriages, which is not affected by the changes in timing, is the cumulative percent ever married at exact age 40 . We consider this as a proxy for the ultimate level, and we calculate it for synthetical cohorts.

Table 5.1 shows the real level of first marriages for the period 1990-1994, in the case of Romania and Bulgaria (GGS data), and for a comparable period 1988-1993 for Hungary (FFS data). One can see that the cumulative percent ever married are systematically higher in Romania, at every age and every gender. Almost 90\% of men and more than $90 \%$ of women ever enter in a first marriage in Romania, while in Bulgaria the percentage is $80 \%-86 \%$. In Hungary there is a bigger gender gap, since only $77 \%$ of men enter in a first marriage before age 40 , while almost $90 \%$ of women do. 
Table 5.1 Cumulative percent ever married by age 30 and 40, by countries

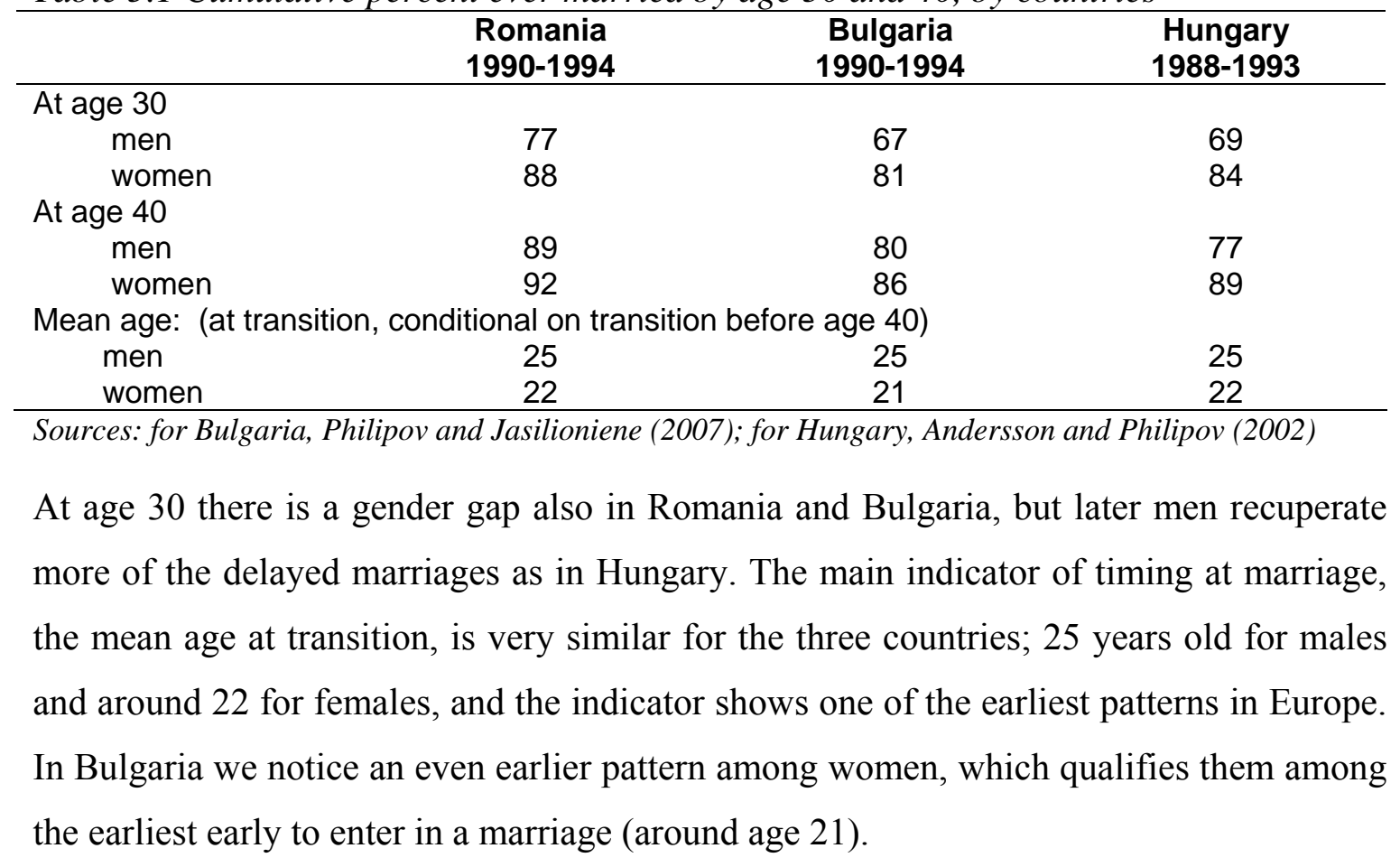

Table 5.2: Cumulative percent ever married

\begin{tabular}{lcccc}
\hline Age & $\begin{array}{c}\text { Men } \\
\mathbf{1 9 8 0 - 1 9 8 9}\end{array}$ & $\begin{array}{c}\text { Men } \\
\mathbf{1 9 9 6 - 2 0 0 5}\end{array}$ & $\begin{array}{c}\text { Women } \\
\mathbf{1 9 8 0 - 1 9 8 9}\end{array}$ & $\begin{array}{c}\text { Women } \\
\mathbf{1 9 9 6 - 2 0 0 5}\end{array}$ \\
\hline & & & & \\
16 & 0 & 0 & 1 & 1 \\
18 & 1 & 0 & 10 & 7 \\
20 & 6 & 2 & 34 & 21 \\
22 & 16 & 10 & 59 & 35 \\
24 & 41 & 25 & 75 & 51 \\
25 & 50 & 33 & 79 & 58 \\
26 & 59 & 40 & 83 & 61 \\
28 & 72 & 51 & 88 & 71 \\
30 & 78 & 60 & 91 & 76 \\
35 & 87 & 72 & 93 & 82 \\
40 & 89 & 76 & 94 & 85 \\
mean age: & & & & \\
(at transition, conditional on transition before age & $40)$ & 22 & \\
& & & & \\
1st decile at age: & 21 & 22 & 18 & 19 \\
1st quartile at: & 23 & 24 & 19 & 21 \\
median at age: & 25 & 28 & 21 & 24 \\
3rd quartile at: & 29 & 38 & 24 & 30 \\
\hline
\end{tabular}


The estimates of first marriage compared above refer to the period immediate after the political shift. Important changes took place since then and we can see the evolutions in Table 5.2, for Romania. The universality of marriage is nearly lost for the synthetical cohort corresponding to the last decade (1996-2005) preceding the survey date. Neither men nor women ever marry in a proportion close to $90 \%$, but women still have a level above 0.8 for first marriages. The cumulative percentage of first marriages at age 40 is now $76 \%$ for males and $85 \%$ for females. The mean age at first marriage increased for both genders, faster for women than for men, attaining 24 and 26 years, respectively ${ }^{5}$.

Figure 5.1: Occurrence / exposure rates for ever married
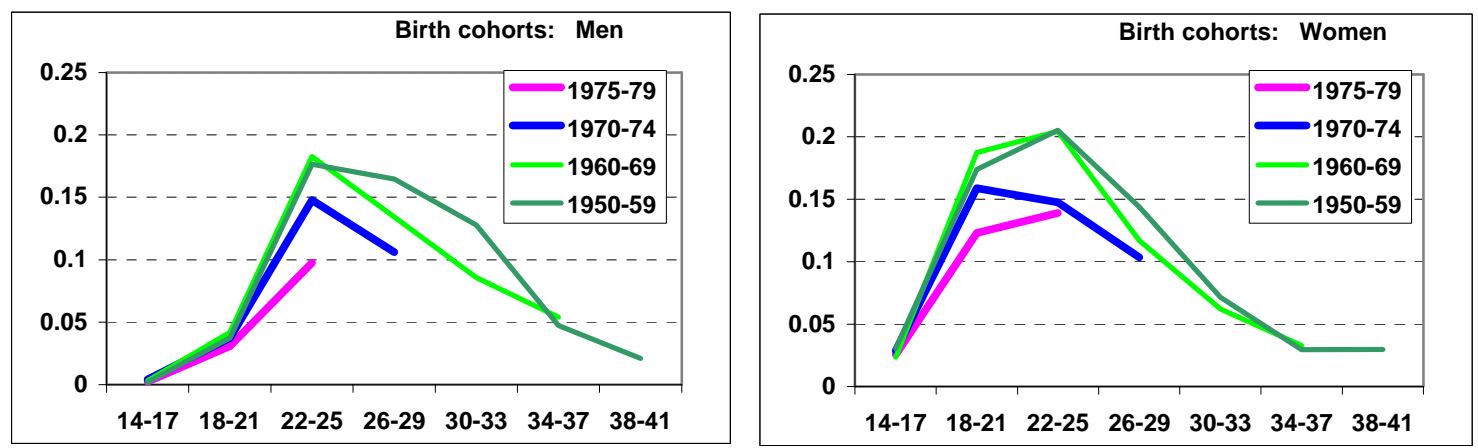

Figure 5.1 shows the first marriage intensities from a birth cohort perspective. Significant changes in the age-patterns occurred both among men and among women. The birth cohort 1960-1969 compared with the birth cohort 1950-1959, had already reduced risk to marry after age 26 , so first a rejuvenation process occurred. The younger cohort 19701974 not only continued to have lower risks of first marriage during age group 26-29, they have had substantively lower risk at all ages below 30 . The female marriage risk at age 22 to 25 almost halved, flattening the marriage age-pattern of this birth cohort. In our analysis, the youngest generation, born between 1975 and 1980, is followed only up to age 30, since it contains individuals not older than this age. Whereas men's risk to ever marry decreased at all ages below 30, women's risk decreased only at ages below 22 . A recuperation process for these women is very probable. The youngest men birth cohort is still in the process of postponement of first marriage and it is impossible as of yet to

\footnotetext{
${ }^{5}$ Same mean ages were attained in Bulgaria by the synthetical cohort 1999-2003 (Philipov and Jasilioniene, 2007)
} 
observe any sign of recuperation, due to the traditional three years age difference in a couple.

We are now able to conclude that there is real change in the marriage pattern, that the postponement is firmly observed, yet the loss of universality is not actually well documented.

\section{First union: single decrement perspective}

Let us now study the first union, regardless if it is a marriage or a non-marital union (referred to in the following as cohabitation).

In the early 1990s the cumulative percent ever in a union at age 40 exceeded $90 \%$ for both genders, and it is slightly higher than in the neighbour countries (Table 5.3). The mean age at union formation is similar, either among men or among women, even if in Hungary it is one year higher. The mean ages 24 and 21, respectively for men and women, are not so unusual for starting a first union in European countries and we cannot qualify union formation in general as having an early pattern, as we did for marriages. The universality is also common in many European countries, and rather the exceptions to this pattern are more interesting to consider, for example West Germany or Italy (see Appendix with life-tables published by Andersson and Philipov 2002). 
Table 5.3: Cumulative percent ever in a union by age 30 and 40, by countries

\begin{tabular}{|c|c|c|c|c|}
\hline 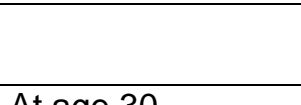 & $\begin{array}{r}\text { Romania } \\
1990-1994\end{array}$ & \multicolumn{2}{|c|}{$\begin{array}{c}\text { Bulgaria } \\
1990-1994\end{array}$} & $\begin{array}{c}\text { Hungary } \\
1988-1993\end{array}$ \\
\hline \multicolumn{5}{|l|}{ At age 30} \\
\hline men & \multicolumn{2}{|l|}{82} & $\begin{array}{l}76 \\
88\end{array}$ & 76 \\
\hline women & 91 & \multirow{2}{*}{\multicolumn{2}{|c|}{88}} & 90 \\
\hline \multicolumn{3}{|l|}{ At age 40} & & \\
\hline men & \multirow{2}{*}{$\begin{array}{l}92 \\
96\end{array}$} & \multicolumn{2}{|c|}{88} & 85 \\
\hline women & & \multicolumn{2}{|c|}{92} & 94 \\
\hline \multicolumn{5}{|c|}{ Mean age: (at transition, conditional on transition before age 40) } \\
\hline men & \multirow{2}{*}{$\begin{array}{l}24 \\
21\end{array}$} & \multirow{2}{*}{\multicolumn{2}{|c|}{$\begin{array}{l}24 \\
21\end{array}$}} & 25 \\
\hline women & & & & 22 \\
\hline \multicolumn{5}{|c|}{ Sources: for Bulgaria, Philipov and Jasilioniene (2007); for Hungary, Andersson and Philipov (2002) } \\
\hline \multirow{2}{*}{\multicolumn{5}{|c|}{$\begin{array}{l}\text { It is more interesting to observe whether there is a change from a period marked by } \\
\text { strong social intervention and control, in our case } 1980-1989 \text {, to a more relaxed period, in } \\
\text { our case } 1996-2005 \text {. Table } 5.4 \text { lists the habitual, from now, life-table indicators. }\end{array}$}} \\
\hline & & & & \\
\hline \multicolumn{5}{|c|}{ Table 5.4: Cumulative percent ever in a union } \\
\hline Age & $\begin{array}{c}\text { Men } \\
1980-1989\end{array}$ & $\begin{array}{c}\text { Men } \\
1996-2005\end{array}$ & $\begin{array}{c}\text { Women } \\
1980-1989\end{array}$ & $\begin{array}{c}\text { Women } \\
1996-2005\end{array}$ \\
\hline 16 & 0 & 0 & 2 & 2 \\
\hline 18 & 2 & 1 & 14 & 11 \\
\hline 20 & 7 & 5 & 39 & 29 \\
\hline 22 & 19 & 15 & 63 & 44 \\
\hline 24 & 45 & 34 & 78 & 62 \\
\hline 25 & 54 & 43 & 83 & 69 \\
\hline 26 & 63 & 49 & 87 & 73 \\
\hline 28 & 75 & 60 & 92 & 81 \\
\hline 30 & 82 & 70 & 94 & 86 \\
\hline 35 & 91 & 81 & 96 & 91 \\
\hline 40 & 93 & 85 & 97 & 92 \\
\hline mean age: & 25 & 26 & 21 & 23 \\
\hline \multicolumn{5}{|c|}{ (at transition, conditional on transition before age 40 ) } \\
\hline 1st decile at age: & 21 & 21 & 18 & 18 \\
\hline 1st quartile at: & 23 & 23 & 19 & 20 \\
\hline median at age: & 25 & 26 & 21 & 23 \\
\hline 3rd quartile at: & 28 & 32 & 23 & 27 \\
\hline
\end{tabular}

The trend is rather towards a postponement in union formation. Interestingly, the men's mean ages at first entry in a union are the same as the mean ages at first marriage, respectively in the two periods, yet they are respectively one year smaller for women. The indicators are not fully comparable since not all first marriages are first unions; some of them can occur after one or more cohabitations. Nevertheless, the similarity of these 
indicators suggests that men enter in a marriage soon after starting a first union, while women could report having cohabitation experience before marriage.

The occurrence /exposure rates of ever in a union (Figure 5.2) show mainly similar transformations from one birth cohort to the next one, as is for marriages, even if the intensities are normally higher. A rejuvenation process took place especially among men from the birth cohort 1960-69: we observe a rise of risks of union formation at age 22-25 and a fall of risks after age 26, compared to the previous cohort. Those born during the 1970s show a different behaviour, starting a postponement process of first unions, but not yet recuperated in later ages. Only for the female youngest birth cohort can the recuperating process be documented: their risk of forming a first union below age 22 was lower, but at age 22-25 it was significantly higher than in the previous cohort. It seems that the 'modernisation' process starts with this very young female generation.

Figure 5.2: Occurrence / exposure rates for ever in a union
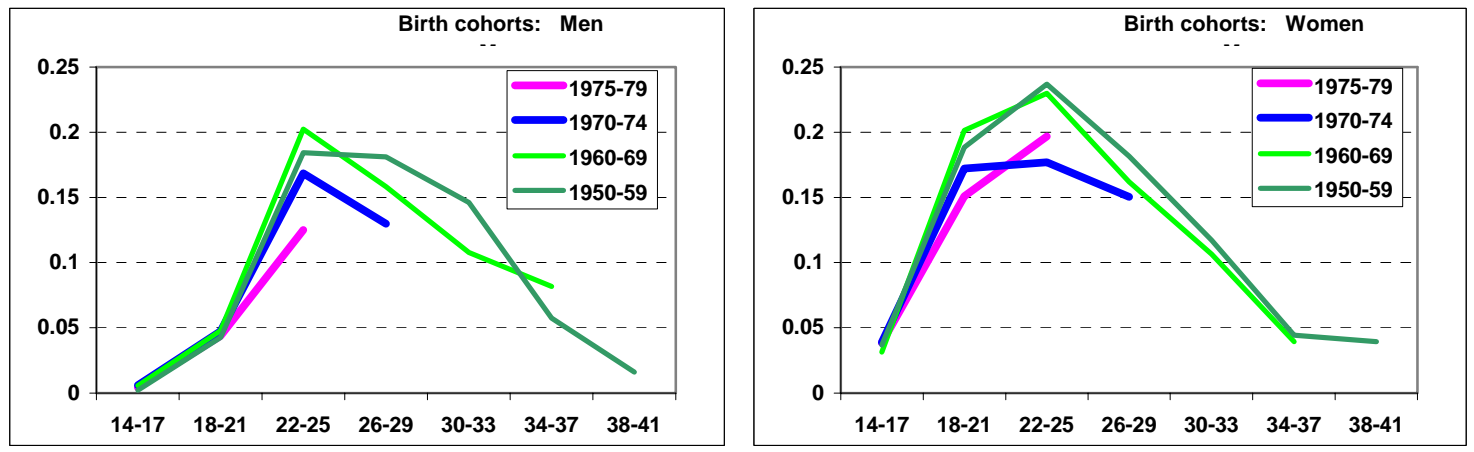

\section{First union: direct marriage or cohabitation?}

The cumulative percentage of ever starting a union can be decomposed in percentages attributed to different decrements. There are two ways of forming a first union: entering either in a direct marriage or in a cohabitation. The competing-risk life-table method gives a good description of the actual fraction of people who will end up either in entering a marital or non-marital union. Both risks are estimated jointly, with each decrement related to the same population of never-partnered individuals. Table 5.5 presents the fractions of men and women who enter their first union by starting to 
cohabitate, and Table 5.6 presents the fractions for direct marriages. The sum at each exact age gives the fraction of the population who ever enter any union at all (Table 5.4).

Table 5.5 shows that women enter into cohabitation at a faster pace than men, and people in more recent years (1996-2005) do it at a faster pace, as was done in former socialist times. The cumulated percentage ever starting a first union as cohabitation at age 40 , is as low in recent times as it was in Hungary around 1990 (see Andersson and Philipov 2002, p: 84), even if it increased by more than 10 percentage points in the last 15 years. This level is far below the $60 \%$ documented for Bulgaria for similar periods (Philipov and Jasilioniene 2007). If the levels of cohabitation differ enormously, the timing indicators are similar among the three neighbour countries.

Table 5.5: Cumulative percent ever starting a first union as cohabitation, competing-risks life-table method with direct marriage as a competing event

\begin{tabular}{|c|c|c|c|c|}
\hline Age & $\begin{array}{c}\text { Men } \\
1980-1989\end{array}$ & $\begin{array}{c}\text { Men } \\
1996-2005\end{array}$ & $\begin{array}{c}\text { Women } \\
1980-1989\end{array}$ & $\begin{array}{c}\text { Women } \\
1996-2005\end{array}$ \\
\hline 16 & 0 & 0 & 1 & 1 \\
\hline 18 & 1 & 1 & 5 & 6 \\
\hline 20 & 3 & 4 & 12 & 13 \\
\hline 22 & 5 & 8 & 15 & 18 \\
\hline 24 & 10 & 15 & 17 & 24 \\
\hline 25 & 11 & 17 & 17 & 27 \\
\hline 26 & 12 & 19 & 18 & 29 \\
\hline 28 & 14 & 22 & 19 & 31 \\
\hline 30 & 16 & 25 & 20 & 33 \\
\hline 35 & 17 & 29 & 20 & 35 \\
\hline 40 & 18 & 30 & 20 & 35 \\
\hline mean age: & 24 & 25 & 20 & 23 \\
\hline \multicolumn{5}{|c|}{ (at transition, conditional on transition before age 40) } \\
\hline 1st decile at age: & 24 & 23 & 19 & 19 \\
\hline 1st quartile at: & - & 30 & - & 24 \\
\hline median at age: & - & - & - & - \\
\hline 3rd quartile at: & - & - & - & - \\
\hline
\end{tabular}

The occurrence / exposure rates (Figure 5.3) for the birth cohorts are very low. They do not exceed 5 non-marital union formations to 100 person-years at any ages, any gender, 
nor in any period. The only one exception is the female youngest birth cohort with the highest risk at age 22-25 (0.07 per woman-year).

Figure 5.3: Occurrence / exposure rates for ever starting a first union as cohabitation
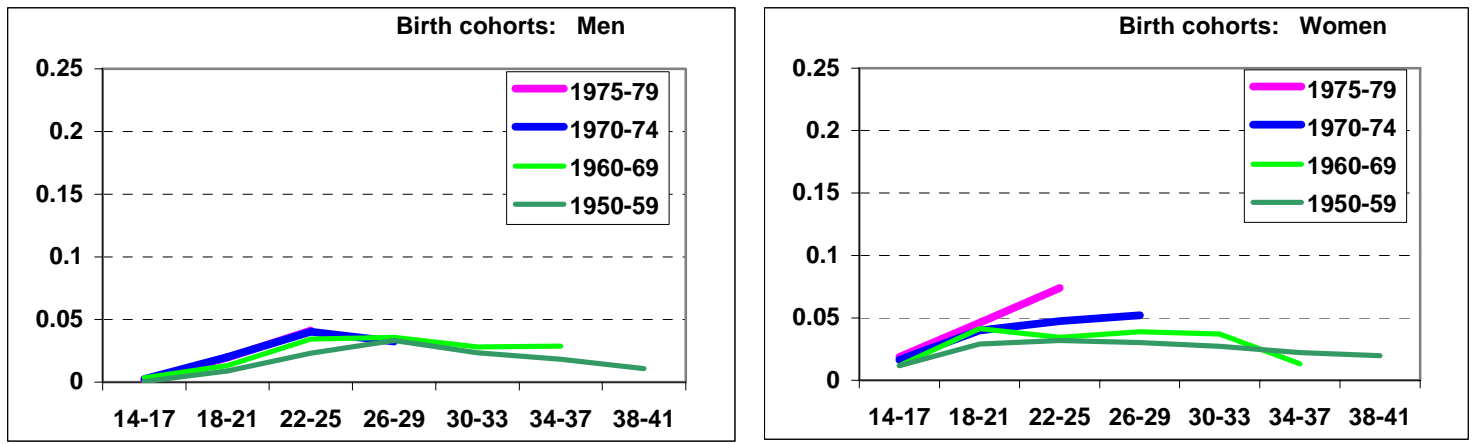

Conversely, direct marriages are more common, even if the fraction of men and women who would enter in a first union as a direct marriage by age 40 (if the probabilities observed during the calendar years of the synthetic cohort had prevailed for a longer period of time), dropped from three quarters to a half, from 1980-1989 to 1996-2005.

Table 5.6: Cumulative percent ever starting a first union as a marriage, competing-risks life-table method with entry into cohabitation as a competing event

\begin{tabular}{lcccc}
\hline Age & $\begin{array}{c}\text { Men } \\
\mathbf{1 9 8 0 - 1 9 8 9}\end{array}$ & $\begin{array}{c}\text { Men } \\
\text { 1996-2005 }\end{array}$ & $\begin{array}{c}\text { Women } \\
\mathbf{1 9 8 0 - 1 9 8 9}\end{array}$ & $\begin{array}{c}\text { Women } \\
\mathbf{1 9 9 6 - 2 0 0 5}\end{array}$ \\
\hline & & & & \\
16 & 0 & & 1 & 1 \\
18 & 1 & 0 & 7 & 5 \\
20 & 4 & 1 & 26 & 15 \\
22 & 12 & 7 & 47 & 26 \\
24 & 34 & 19 & 61 & 37 \\
25 & 42 & 25 & 65 & 41 \\
26 & 50 & 30 & 68 & 44 \\
28 & 61 & 38 & 73 & 50 \\
30 & 66 & 45 & 74 & 53 \\
35 & 73 & 52 & 76 & 56 \\
40 & 75 & 55 & 76 & 57 \\
mean age: & & & & \\
(at transition, conditional on transition before age & $40)$ & 22 & \\
1st decile at age: & 25 & & & \\
1st quartile at: & 21 & 23 & 18 & 23 \\
median at age: & 23 & 25 & 20 & 28 \\
3rd quartile at: & 26 & 33 & 22 & - \\
\hline
\end{tabular}


It is logical that the hazard rates of ever enter a first marriage and of starting a first union as direct marriage are similar, also in a birth cohort perspective. The two Figures, 5.4 and 5.1, appear to be the same even if they are not, and minor differences do exist.

Figure 5.4: Occurrence / exposure rates for ever starting a first union as marriage
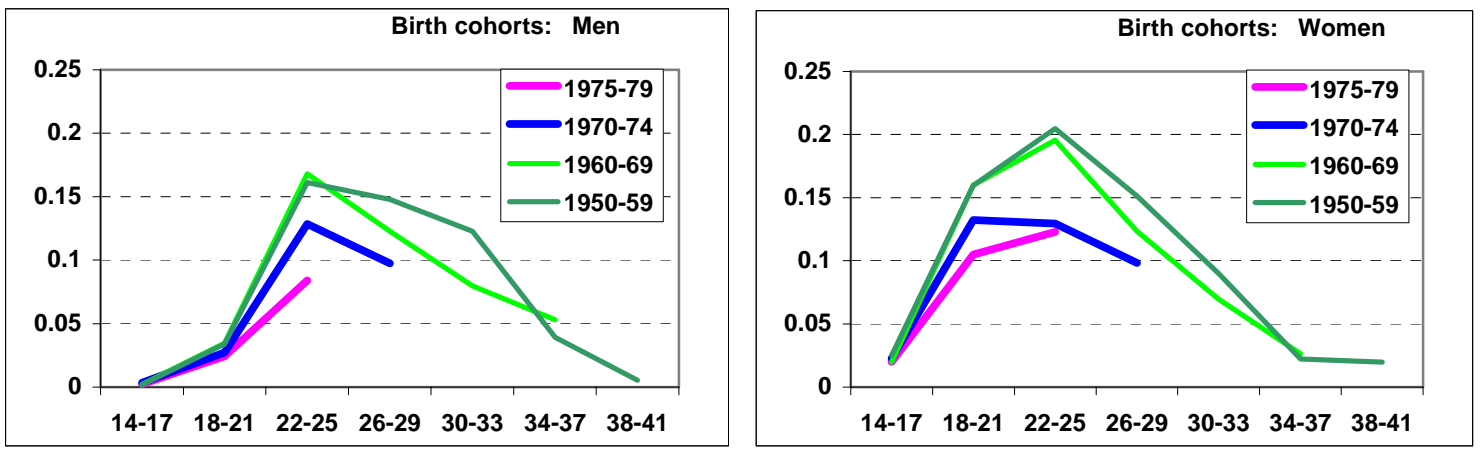

Up to now, our findings from life-table indicators lead us to similar conclusions as the macro-indicators-based analysis had previously brought us, in section 3. The spread of cohabitation as an alternative to marriage is not wide enough (criterion 9, from Table 3.1 ), and the never married young women are not sufficiently numerous (criterion 10) to fulfill the requirements for the onset of the Second Demographic Transition in Romania.

\section{First cohabitation transformation}

For having a deeper insight into what happens with cohabitations, we now leave the perspective of the individual, and we take the couple as a unit for analysis. In this section we study first unions that started as cohabitations and we look forwards to see their destinies: cohabiting couples can marry after a while, they can separate or they can remain together "forever", i.e. until the death of one of the partners. The former are those who first want to try if they can live together before proceeding to a wedding; they can succeed or fail. The latter are those who really don't believe in marriage as an institution.

In this section we consider all responses, of both sexes taken together. 


\section{Duration of first cohabitation: marriage or separation?}

Tables 6.1, 6.2, and 6.3 provide cumulative percentages of either married or separated, treated as competing risks: one of the events compete with the other. Table 6.4 add up the cumulative percentages and shows an overall picture of those who experience one of the two events, and (by complement of 100) of those who remain in cohabitation.

We compare Romania with Bulgaria and Hungary for the period 1990-1994 (around this period in the case of Hungary, i.e. 1988-1993) following only the first five years of cohabitation, because the number of the population at risk in Bulgaria (based only on responses of female respondents unlike the analisis for Romania and Hungary which are based on responses of both sexes) falls under the minimum of 15 necessary couples to maintain comparisons.

Table 6.1: Cumulative percent married by time since formation of a consensual union, by countries, competing risk separation

\begin{tabular}{|c|c|c|c|}
\hline Duration in years & $\begin{array}{c}\text { Romania } \\
1990-1994\end{array}$ & $\begin{array}{c}\text { Bulgaria } \\
1990-1994\end{array}$ & $\begin{array}{c}\text { Hungary } \\
1988-1993\end{array}$ \\
\hline 1 & 43 & 63 & 24 \\
\hline 2 & 61 & 74 & 36 \\
\hline 3 & 67 & 79 & 42 \\
\hline 5 & 74 & 83 & 47 \\
\hline Median duration & 1.1 & 0.5 & 7 \\
\hline
\end{tabular}

Half of cohabitations turn into marriages in Romania before one year, while in Bulgaria this happens sooner, during only half a year. In Hungary the pace of marriage is much slower; it takes 7 years until half of first unions turn into marriages. At five years duration of cohabitation, three-quarters of Romanian couples marry, which is by 10 percentual points less than the Bulgarians, but significantly more than $47 \%$ of Hungarian couples. 
Table 6.2: Cumulative percent married, by time since formation of a consensual union, competing-risks life-table method with separation as a competing event

\begin{tabular}{lcc}
\hline Duration in years & $\mathbf{1 9 8 0 - 1 9 8 9}$ & $\mathbf{1 9 9 6 - 2 0 0 5}$ \\
\hline & & \\
1 & 45 & 27 \\
2 & 63 & 45 \\
3 & 68 & 52 \\
4 & 71 & 57 \\
5 & 74 & 60 \\
7 & 77 & 62 \\
10 & 79 & 64 \\
15 & 80 & 66 \\
& & \\
mean duration: & & \\
(at marriage / conditional on marriage within 15 years) & 1.5 & 1.9 \\
& & \\
1st decile: & 0 & 0 \\
1st quartile: & 0 & 1 \\
median: & 1 & 2 \\
3rd quartile: & 6 & - \\
\hline
\end{tabular}

Before 1990, the pace of marriages was faster in Romania, as Table 6.2 shows, but it slowed down during the market economy period. Half the couples of the synthetical cohort 1996-2005 will not marry before three years of free union, and one third will not marry even before 15 years of cohabitation. However, the percentage now in Romania is less than the $40 \%$ of Bulgarian couples from the synthetical cohort 1999-2003 who will not marry within 15 years (Philipov and Jasilioniene 2007). The mean duration of first cohabitation transformed into marriage increased very little (from 1.5 years to 1.9 years) from socialist times to market times (in Romania).

In contrast to marriage, separation became more widespread. The cumulated percentage of separations up to the exact duration of 15 years of cohabitation increased from $8 \%$ to $20 \%$, but, again, the mean duration (of failed cohabitations) changed only little. It remained close to four years (Table 6.3).

Taken together, marriage and separation, show that the great majority of first unions that started as cohabitations, transformed up until duration of 15 years (see Table 6.4). The question is if the remaining percentages, i.e. $11 \%$ in $1980-1989$ and $14 \%$ in $1996-2005$, 
represent post-modern couples? Or, maybe, are they couples at the margin of society living in precarious conditions, who do not permit themselves to register their union? This question remains to be answered by other studies.

Table 6.3: Cumulative percent separated, by time since formation of a consensual union, competing-risks life-table method with marriage as a competing event

\begin{tabular}{lcc}
\hline Duration in years & $\mathbf{1 9 8 0 - 1 9 8 9}$ & $\mathbf{1 9 9 6 - 2 0 0 5}$ \\
\hline 1 & 1 & 3 \\
2 & 3 & 5 \\
3 & 5 & 7 \\
4 & 6 & 9 \\
5 & 6 & 12 \\
7 & 6 & 15 \\
10 & 7 & 17 \\
15 & 8 & 20 \\
& & \\
mean duration: & & 4.6 \\
(at union disruption / conditional on disruption within 15 years) & \\
1st decile: & - & \\
1st quartile: & - & - \\
median: & - & - \\
3rd quartile: & - & - \\
\hline
\end{tabular}

=> Table 6.4: Cumulative percent no longer in a consensual union, by time since union formation

\begin{tabular}{lcc} 
Duration in years & $\mathbf{1 9 8 0 - 1 9 8 9}$ & $\mathbf{1 9 9 6 - 2 0 0 5}$ \\
1 & 50 & 34 \\
2 & 68 & 51 \\
3 & 73 & 61 \\
4 & 77 & 67 \\
5 & 80 & 72 \\
7 & 83 & 77 \\
10 & 86 & 81 \\
15 & 89 & 86 \\
mean duration: & & \\
(at exit / conditional on exit within 15 years) & 1.7 & 2.5 \\
1st decile: & & \\
1st quartile: & 0 & 0 \\
median: & 0 & 1 \\
3rd quartile: & 1 & 2 \\
\hline
\end{tabular}


The mean duration at transformation increased by 0.8 years during the one and a half decades which separate the two periods.

\section{Transformation of first cohabitation: childbearing, separation or marriage?}

Childbearing can accelerate the union transformation. It is a transformation in itself; cohabiting couples are pushed to take a decision regarding their marriage or their separation once they (know they will) become parents. Therefore, in the following, we consider three competing risks for cohabitation transformation: childbirth, separation and marriage.

Each of the following three Tables - 6.5, 6.6 and 6.7 - represent one of the risks, when the other two are considered as competing risks. There are no cumulative percentages for higher durations than 4-7 years in either table (with the singular exception of entry into parenthood in 1996-2005), because of the small number of the population at risk beyond 4-7 years of cohabitation. Only the summing Table 6.8, where all the three risks are taken together, shows the share of cohabiting couples not experienced in any of the three events. Actually, Table 6.8 shows that almost all couples experience one of the three events, before 15 years of cohabitation, and that the mean duration at transformation is very short: 1.3 years during socialist times and 1.8 years during post-socialist times. 
Table 6.5: Cumulative percent parents, by time since formation of a consensual union by childless couple, competing risks separation and marriage

\begin{tabular}{lcc} 
Duration in years & $\mathbf{1 9 8 0 - 1 9 8 9}$ & $\mathbf{1 9 9 6 - 2 0 0 5}$ \\
1 & 14 & 9 \\
2 & 24 & 20 \\
3 & 27 & 24 \\
4 & 29 & 27 \\
5 & - & 28 \\
7 & - & 29 \\
10 & - & 29 \\
15 & - & 30 \\
mean duration: & & \\
(at birth / conditional on birth within 15 years) & 1.4 & 2.0 \\
& & \\
1st decile: & & 1 \\
1st quartile: & 1 & 3 \\
median: & 2 & - \\
3rd quartile: & - & - \\
\hline
\end{tabular}

Table 6.6: Cumulative percent separated, by time since formation of a consensual union by childless couple, competing risks childbirth and marriage

\begin{tabular}{lcc} 
Duration in years & $\mathbf{1 9 8 0 - 1 9 8 9}$ & $\mathbf{1 9 9 6 - 2 0 0 5}$ \\
1 & 1 & 3 \\
2 & 2 & 5 \\
3 & 3 & 7 \\
4 & 4 & 8 \\
5 & 4 & 11 \\
7 & - & 12 \\
10 & - & - \\
15 & - & - \\
& & 3.6 \\
mean duration: & 3.0 & \\
(at union disruption / conditional on disruption within 15 years) & 4 \\
1st decile: & - & - \\
1st quartile: & - & - \\
median: & - & - \\
3rd quartile: & - & \\
\hline
\end{tabular}


Table 6.7: Cumulative percent married, by time since formation of a consensual union by childless couple, competing risks childbirth and separation

\begin{tabular}{lcc}
\hline Duration in years & $\mathbf{1 9 8 0 - 1 9 8 9}$ & $\mathbf{1 9 9 6 - 2 0 0 5}$ \\
\hline 1 & 43 & 26 \\
2 & 54 & 40 \\
3 & 58 & 46 \\
4 & 58 & 49 \\
5 & 60 & 51 \\
7 & - & 52 \\
10 & - & - \\
15 & - & - \\
& & \\
mean duration: & 1.1 & 1.3 \\
(at marriage / conditional on marriage within 15 years) & & \\
& & \\
1st decile: & 0 & 0 \\
1st quartile: & 0 & 1 \\
median: & 1 & - \\
3rd quartile: & - & - \\
\hline
\end{tabular}

The first of these tables, Table 6.5 , shows that almost $30 \%$ of cohabiting couples have a child soon after cohabiting begins; within the first 4 years of cohabitation. During postsocialist times an out-of-wedlock birth has been slightly postponed, yet the level has not increased significantly.

Within four years since union formation, only $4 \%$ of first cohabiting couples separated during socialist times, but twice more separated in recent times $(8 \%)$, as is shown by Table 6.6. However, the level of separation among cohabiting couples, as first transformation of their couple, remains low. Much more often marriage is the next common step. It is possible that couples enter into marriage after first conception, but before the birth of the child. In our analysis we have considered the date at first birth and not the date at first conception (ending in a birth), though we do not know the share of "shotgun" marriages ${ }^{6}$.

Indeed, as Table 6.7 shows, $60 \%$ of cohabiting couples transformed their relationship into marriage in the period 1980-1989. Eight percent fewer married in the last period, but they

\footnotetext{
${ }^{6} \mathrm{We}$ deal with this later, in the next section (section 7)
} 
are still the majority among all kinds of transformations. Moreover, marriage happens quickly, soon after the first year of cohabitation, regardless of the period of analysis.

$=>$ Table 6.8: Cumulative percent transformation of a consensual union, by time since union formation

\begin{tabular}{lcc}
\hline Duration in years & $\mathbf{1 9 8 0 - 1 9 8 9}$ & $\mathbf{1 9 9 6 - 2 0 0 5}$ \\
\hline & & \\
1 & 61 & 43 \\
2 & 81 & 66 \\
3 & 89 & 77 \\
4 & 91 & 86 \\
5 & 94 & 90 \\
7 & 95 & 93 \\
10 & 97 & 94 \\
15 & 98 & 96 \\
mean duration: & 1.3 & \\
(at exit / conditional on exit within 15 years) & & \\
1st decile: & & \\
1st quartile: & 0 & 0 \\
median: & 0 & 1 \\
3rd quartile: & 1 & 1 \\
\hline
\end{tabular}

We can conclude, on the one hand, that most of first cohabitations transform quickly, either by childbirth or by marriage (on average 1-2 years). On the other hand, only a decision for separation takes longer (on average 3-4 years). The time elapsed since union formation and its transformation increased slightly from one period to the other; no more than by half a year. The most common transformations remained marriage, then childbirth and the last, separation.

\section{First marriage transformation}

This section deals with first marriages. We have taken into consideration all first marriages, regardless if they were direct marriages, or marriages following first unions started as cohabitations, or if they occurred after several cohabitations. 
The first part of the section looks at duration of marriage and the second part looks at the first transformation of childless marriage; either childbirth or divorce.

\section{Duration of first marriage: divorce or partner's death?}

A marriage can end by divorce or can end by the death of one of the partners. If we want to study the duration of marriages we have to consider both of these events as competingrisks, as Philipov and Jasilioniene did in their recent study (2007).

Even if in this analysis the couple is the statistical unit, as in the case of first cohabitation, we have excluded the responses of male respondents, because the higher mortality of men could bias the results. There is a well-known gap between the mortality of the two sexes. During the last decade and a half Romanian women have had an increased life expectancy at birth by around 7 years. Advanced-age marriages may come to an end owing to the death of the partner: as mortality is higher among males it is likely that the sample will include a larger number of widowed women than men.

Table 7.1: Cumulative percent of first marriages ending by divorce by time since start of the marriage, competing risk death of partner (based on responses of female respondents)

\begin{tabular}{lcc}
\hline Duration in years & 1980-1989 & $\mathbf{1 9 9 6 - 2 0 0 5}$ \\
\hline 5 & 4 & 4 \\
10 & 7 & 8 \\
15 & 10 & 11 \\
20 & 12 & 13 \\
25 & 13 & 14 \\
30 & 14 & 15 \\
40 & 14 & 16 \\
50 & - & 16 \\
& & 11 \\
mean duration: & 10 & \\
(at divorce / conditional on ending within 25 years) & & 14 \\
& & - \\
1st decile: & 14 & - \\
1st quartile: & - & - \\
median: & - & \\
3rd quartile: & - & \\
\hline
\end{tabular}


The level of divorce is not higher than $14 \%-16 \%$, as Table 7.1 shows. A small increase by $2 \%$ is observed between the two periods, and this is due to a slightly faster pace of divorce. The mean duration of first marriages ending in divorce increased from 10 to 11 years from one period to the other, which documents for the stability of marriages in Romania.

We have comparable data only for Bulgaria, but not for Hungary. Very similar levels of divorce were observed in Bulgaria). The increased duration of broken marriages was also noticed in Bulgaria, but is 2 years shorter (7 years during 1985-1989, and 9 years during 1999-2003) than in Romania.

Table 7.2: Cumulative percent of first marriages ending because of the death of the husband, by time since start of the marriage, competing risk divorce (based on responses of female respondents)

\begin{tabular}{lcc}
\hline Duration in years & 1980-1989 & 1996-2005 \\
\hline 5 & 0 & 1 \\
10 & 1 & 1 \\
15 & 2 & 2 \\
20 & 4 & 4 \\
25 & 6 & 7 \\
30 & 10 & 12 \\
40 & 21 & 25 \\
50 & 32 & 45 \\
& & \\
mean duration: & 26 & 29 \\
(at the death of the partner / truncated after 40 years) & & \\
& & \\
1st decile: & 30 & 28 \\
1st quartile: & 42 & 40 \\
median: & - & - \\
3rd quartile: & - & - \\
\hline
\end{tabular}

The end of marriage due to the death of the male partner is a rare event before 30 years of marriage (Table 7.2). However, the cumulative percent of first marriages ending because of the death of the husband increased by $2 \%$ (from $10 \%$ to $12 \%$ ) from one period to the other. At duration 50,32\% of marriages ended in the synthetical cohort 1980-1989 and $45 \%$ in the synthetical cohort 1996-2005. The increasing adult male mortality (aged 30- 
59) in Romania during the 1990s, was documented by Mureşan (1999b) and naturally it influenced the pace and the durability of marriages, at least when data relies on marriages reported by surviving women during a period of increasing female life expectancy.

The longevity of ended marriages increased by 3 years, from 26 years in socialist times to 29 years in post-socialist times (if we do not consider the marriages ended by divorce). In Bulgaria the trend is similar, meaning the longevity of marriages increased from 25 to 28 years, from the late 1980 s to the early 2000 .

If we consider all ended marriages, either by divorce or by the death of the male partner, the mean longevity is normally lower. In recent times the mean duration is 24 years, which is 5 years longer than in older times. Table 7.3 shows these figures.

$=>$ Table 7.3: Cumulative percent first marriages ended, by time since start of the marriage (based on responses of female respondents)

\begin{tabular}{lcc}
\hline Duration in years & $\mathbf{1 9 8 0 - 1 9 8 9}$ & $\mathbf{1 9 9 6 - 2 0 0 5}$ \\
\hline 5 & 4 & 5 \\
10 & 8 & 9 \\
15 & 12 & 13 \\
20 & 16 & 17 \\
25 & 20 & 21 \\
30 & 23 & 27 \\
40 & 35 & 41 \\
50 & - & 61 \\
& & \\
mean duration: & 19 & 24 \\
(at the end of union/ conditional on ending within 40 years) & \\
& & \\
1st decile: & 12 & 11 \\
1st quartile: & 32 & 29 \\
median: & - & 45 \\
3rd quartile: & - & - \\
\hline
\end{tabular}

The complement to 100 of the cumulative percent at duration 25 from Table 7.3 gives us the percentage of couples who will celebrate their "silver" wedding anniversary, and the complement to 100 at duration 50 gives us the percentage of those who will celebrate their "golden" wedding anniversary (if the divorce rates and death rates remain the same as in the period to which the life-tables refer). It means that about $80 \%$ of first marriages 
celebrate their "silver" wedding regardless of the period, and about $40 \%$ of first marriages will celebrate their "golden" wedding in the more recent period. We cannot comment on the "golden" wedding in the older period because the population at risk, who would have more than 50 years of marriage, are in their $80 \mathrm{~s}$, and are lacking in our sample. At the moment of interview respondents would have to be more than 86 years old, if we take into account the mean age 21 at first marriage, and then add the necessary 50 years of marriage, and the 15 years elapsed since 1990. There are no such women in the sample, where the maximum age is 79 .

In Bulgaria similar percentages ( $81 \%-82 \%)$ will celebrate their "silver" wedding anniversary, and about half of them (by more than $10 \%$ as compared to Romanian couples) will celebrate their "golden" wedding anniversary if the patterns shown by the synthetical cohort 1999-2003 do not change, as shown by Philipov and Jasilioniene (2007).

\section{Transformation of first marriage: childbearing or divorce?}

As we did earlier for first cohabitation, we are interested to see how childbearing affects first marriage transformation of childless couples. We are interested especially to estimate the interval between the marriage and the first birth in that marriage, and to what extent childless couples divorce. We apply a competing-risk life-table method where we consider two competing risks: childbearing and divorce. We left out the death of the partner as a third competing risk because childless couples whose marriages end by the death of one of the partners are extremely rare, since childbearing is almost universal in Romania. Because differential mortality between men and women cannot affect our analysis, the next three life-tables are, again, based on responses of both sexes, as in the analysis of transformation of cohabitation.

Table 7.4 displays level and timing estimates of marital-birth when divorce is a competing risk, Table 7.5 displays similar indicators when a childless couple divorces (birth is a competing risk), and Table 7.6 sums up the two risks and estimate levels and timing of first transformation of a marriage. Our aim is to compare the two kinds of transformations with similar transformation in cohabitation: marital-birth with out-of- 
wedlock-birth, and divorce with separation. We recall that a third competing risk exists in the case of cohabitation, that is its' transformation in a marriage. Some conceptions in first cohabitation count as birth in first marriage, if the marriage occurred before the birth. The first line in Table 7.4 shows mainly these situations.

Table 7.4: Cumulative percent parents, by time since a first marriage of childless couple, competing risk divorce (based on responses of both sexes)

\begin{tabular}{lcc}
\hline Duration in years & $\mathbf{1 9 8 0 - 1 9 8 9}$ & $\mathbf{1 9 9 6 - 2 0 0 5}$ \\
\hline before 0.6 (7 months) & 12 & 11 \\
1 & 30 & 23 \\
2 & 60 & 49 \\
3 & 72 & 63 \\
4 & 77 & 70 \\
5 & 81 & 74 \\
7 & 84 & 79 \\
10 & 86 & 82 \\
15 & 88 & 83 \\
mean duration: & & \\
(at birth / conditional on birth within 15 years) & 2.1 & 2.4 \\
1st decile: & & \\
1st quartile: & 1 & 1 \\
median: & 1 & 1 \\
3rd quartile: & 1 & 2 \\
\hline
\end{tabular}

About 11\%-12\% of births are conceived before the marriage, but we have not observed any substantial change between the two periods. A great majority of couples have a first birth in the first marriage: $88 \%$ in the period $1980-1989$ and $83 \%$ in the period 1996 2005.

Birth occurs very soon after marriage, the mean interval between the marriage and first birth is 2 years. Again we do not observe a substantial change between periods, only a slight increase by 4 months.

The above-mentioned mean interval between marriage and birth is, however, slightly greater than the mean interval between union formation of cohabiting couples and their first birth (see Table 6.5), where the childbirth is even more precipitated. The finding may suggest that cohabitation is, rather, a union form used by people of low socio- 
economic status who could care less whether a birth arrives sooner or later, than a "trial" period before marriage where birth should occur later.

Childless marriages are rare and only 3\%-4\% of all first marriages break up before a birth, as Table 7.5 shows. The level of divorce is smaller than the level of split cohabitation, especially when we refer to the more recent period, which has witnessed an increase in consensual union separations. Childless cohabitations are more unstable than childless marriages, since $12 \%$ of them end in separation before exact duration of 7 years, while only $4 \%$ of childless marriages end in separation as the first event of transformation (in the 1996-2005 synthetical cohort).

Table 7.5: Cumulative percent divorced, by time since first marriage of a childless couples, competing risk childbirth (based on responses of both sexes)

\begin{tabular}{lcc}
\hline Duration in years & $\mathbf{1 9 8 0 - 1 9 8 9}$ & $\mathbf{1 9 9 6 - 2 0 0 5}$ \\
\hline & & \\
1 & 0 & 1 \\
2 & 1 & 1 \\
3 & 1 & 2 \\
4 & 2 & 2 \\
5 & 2 & 2 \\
7 & 2 & 4 \\
10 & 3 & 4 \\
15 & 3 & 5.2 \\
mean duration: & 5.4 & \\
(at union disruption / conditional on disruption within 15 years) & \\
& & - \\
1st decile: & - & - \\
1st quartile: & - & - \\
median: & - & \\
3rd quartile: & - & \\
\hline
\end{tabular}

The above finding is also documented by the mean duration of the broken childless union, which in the last period is 3.6 years in case of cohabitations, but 5.2 years in case of marriages. Neither the level nor the duration of divorce changed significantly across time.

Childless married couples do not survive in a greater proportion than $9 \%$ in the synthetical cohort of socialist times, or more than $13 \%$ in the synthetical cohort of market 
times (Table 7.6). At exact duration 15 years, $91 \%$ and $87 \%$, respectively, of marriages were transformed (birth or divorce). The mean duration of the childless period of two married persons increased only slightly from 2.2 years to 2.6 .

$=>$ Table 7.6: Cumulative percent transformation of the first marriage, by time since marriage (based on responses of both sexes)

\begin{tabular}{lcc}
\hline Duration in years & $\mathbf{1 9 8 0 - 1 9 8 9}$ & $\mathbf{1 9 9 6 - 2 0 0 5}$ \\
\hline 1 & 35 & 26 \\
2 & 63 & 52 \\
3 & 74 & 66 \\
4 & 79 & 72 \\
5 & 83 & 77 \\
7 & 86 & 82 \\
10 & 89 & 85 \\
15 & 91 & 87 \\
mean duration: & & \\
(at marriage transformation / conditional on transformation within 15 years) & 2.6 \\
1st decile: & & \\
1st quartile: & 1 & 1 \\
median: & 1 & 1 \\
3rd quartile: & 2 & 2 \\
\hline
\end{tabular}

In conclusion we did not find any major change in behaviour of first married couples, from one period to the other.

\section{Parenting}

The downward trend of the total fertility rate (TFR) is one of the best documented after the political change in 1989. After a rapid fall from 2.2 children per women in 1989 to 1.3 children per women in 1995, the low level has stabilized in the most recent decade. We have seen, in section 3, that this was due to a diminished contribution to TFR by women younger than 25 years old, which was not totally compensated by later age fertility. Part of the decrease of TFR is explained by the fertility postponement, since this indicator is very sensitive to rapid timing changes, but real level (intensity) decreases 
could also affect this indicator. Sobotka (2003) calculated adjusted total fertility rates by birth order (which are not affected by the timing changes) and showed that in the case of Romania, Bulgaria, and Russia, fertility has been mainly reduced by the decrease of second order births (level effect), while in other countries of central Europe the fertility decreased mainly due to the postponement of first birth (timing effect).

In the following we consider separately first birth, and second birth, in order to emphasise the changes occurred in level and timing of each birth order, from one period to the other. We also take a look at differences in hazard rates between birth cohorts.

\section{First birth (or transition to parenthood)}

At the beginning of the transition period, Romania, Bulgaria, and Hungary seem to have very similar patterns in transition to parenthood (Table 8.1). At age 30 about $85 \%$ of women and about $65 \%$ of men are already parents. At age 40 , around $90 \%$ of women and $80 \%$ of men are in this situation, which supports the hypothesis that the well-known universality of motherhood in east European countries is still up to date. Universality of fatherhood is not attained; they usually have, by about $10 \%$, more childlessness at the end of their reproductive life (considered here 50 years old) than women. It is possible that men do not report children who have been born out of cohabitation or wedlock, they simply do not know about the existence of some of their children who are usually born to lone mothers, or simply there are more men than women who do not have children. Early entry into parenthood is also up to date since the mean age at first birth is below 25 for all three countries among women; the men being, on average, 2-3 years older than women when they become fathers. The earliest pattern is in Bulgaria, followed by Romania, and last by Hungary. 
Table 8.1: Cumulative percent ever parent by age 30 and 40, by countries

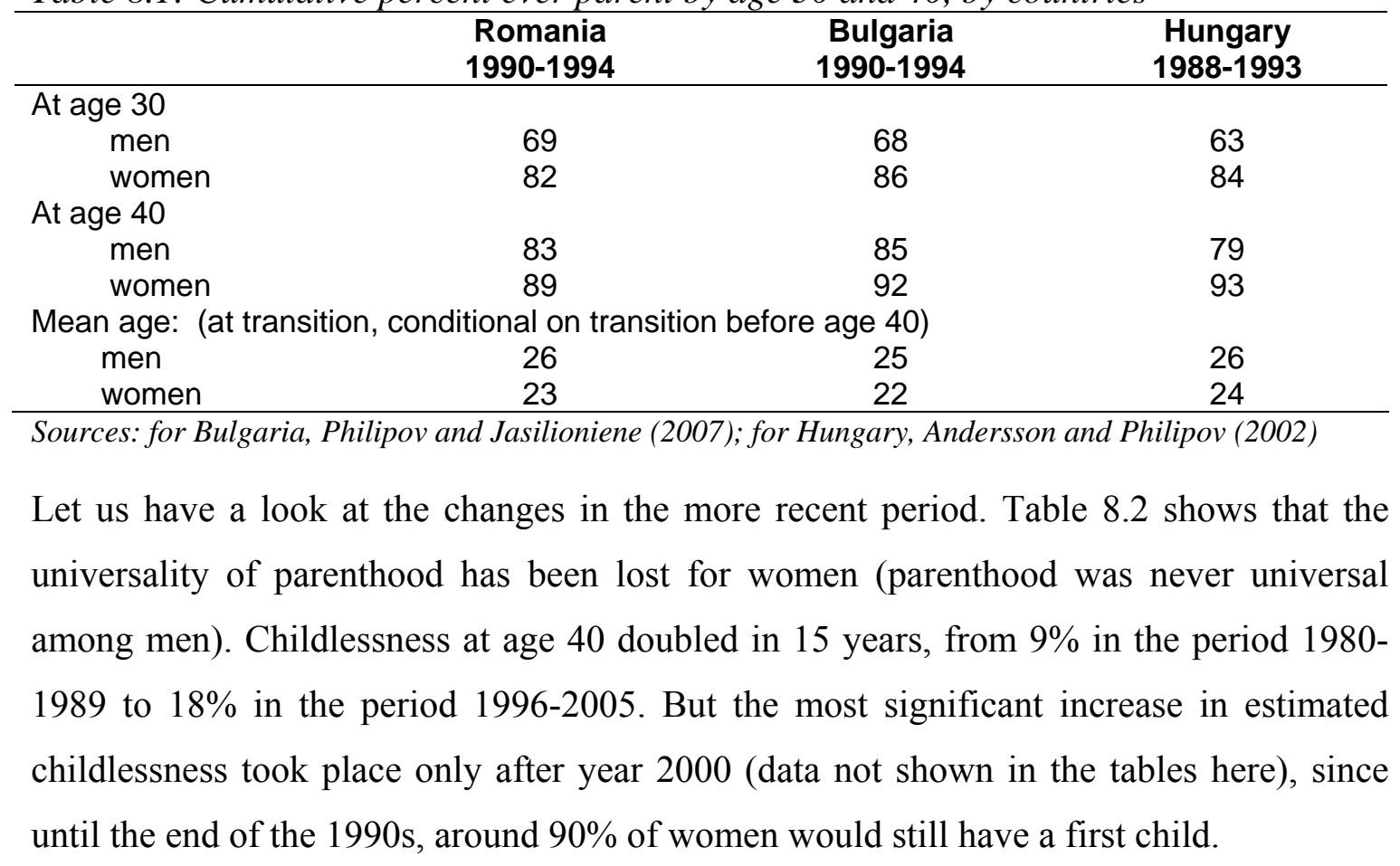

Table 8.2: Cumulative percent ever parent (only biological children)

\begin{tabular}{lcccc}
\hline Age & $\begin{array}{c}\text { Men } \\
\text { 1980-1989 }\end{array}$ & $\begin{array}{c}\text { Men } \\
\text { 1996-2005 }\end{array}$ & $\begin{array}{c}\text { Women } \\
\mathbf{1 9 8 0 - 1 9 8 9}\end{array}$ & $\begin{array}{c}\text { Women } \\
\mathbf{1 9 9 6 - 2 0 0 5}\end{array}$ \\
\hline & 0 & & 1 & 1 \\
16 & 1 & 0 & 6 & 4 \\
18 & 4 & 2 & 22 & 15 \\
20 & 9 & 5 & 44 & 29 \\
22 & 24 & 16 & 61 & 44 \\
24 & 33 & 23 & 69 & 50 \\
25 & 43 & 30 & 72 & 55 \\
26 & 58 & 42 & 80 & 64 \\
28 & 68 & 53 & 85 & 71 \\
30 & 79 & 67 & 90 & 80 \\
35 & 83 & 72 & 91 & 82 \\
40 & & & & \\
& 27 & 28 & 23 & \\
mean age: & & & & 20 \\
(at transition, conditional on transition before age & $40)$ & 19 & 21 \\
1st decile at age: & 22 & 23 & 20 & 25 \\
1st quartile at: & 24 & 25 & 23 & 32 \\
median at age: & 27 & 29 & 27 & \\
3rd quartile at: & 33 & - & & \\
\hline
\end{tabular}


Men and women have postponed their first birth by 2 years from one period to the other, as median age at birth shows. Half the men would have entered parenthood before age 29 in the period 1996-2005, while they would have entered even before age 27 in the earlier period, if the fertility patterns of the respective periods had remained unchanged. Only at age 25 would women have attained the same level of entering parenthood $(50 \%)$ in the most recent period, while at age 23 half of them would have already been mothers during the socialist times.

To sum up, we have found both level and timing changes over the two periods in first order fertility. But as everywhere, in Romania there are trendsetters and laggers, and education probably is one of the important factors playing into the fertility trend. Table 8.3 shows the differences between three differently educated categories of women, where education is reported as the highest level attended at the moment of interview (December 2005). Even if this level maynot be the same as the woman had at her first birth ${ }^{7}$, a first impression about educational differentiation is worthwhile.

During socialist times almost every low-educated and middle-educated women had a first child (above 90\%), and highly-educated women followed, also in a very high percentage (86\%). Ultimate childlessness increased during post-socialist times only among middleeducated (18\%) and highly-educated women (23\%); remaining unchanged among loweducated women (9\%). First birth postponement also took place only among those with at least upper-secondary education. The median age at first birth remained unchanged (21 years) among the low-educated, but it increased by 2 years for those with uppersecondary education (from 23 to 25 years), and respectively by 4 years among those with post-secondary education (from 26 to 30 years). These evolutions have produced a deeper polarization than it was during socialist times among differently educated women, both regarding the level and the timing at first birth.

\footnotetext{
${ }^{7}$ The best solution would be considering a "current" educational level as a time-varying variable, instead of the time-constant variable of "final" educational attainment. Unfortunately the first wave of GGS did not collect education histories, so we have to rely on the educational level at the moment of interview.
} 
Table 8.3: Cumulative percent ever mother, by final educational level (only biological children of women respondents)

\begin{tabular}{|c|c|c|c|c|c|c|}
\hline Age & $\begin{array}{l}\text { No upper- } \\
\text { secondary } \\
1980-1989\end{array}$ & $\begin{array}{c}\text { Upper- } \\
\text { secondary } \\
1980-1989\end{array}$ & $\begin{array}{c}\text { Post- } \\
\text { secondary } \\
1980-1989\end{array}$ & $\begin{array}{l}\text { No upper- } \\
\text { secondary } \\
1996-2005\end{array}$ & $\begin{array}{c}\text { Upper- } \\
\text { secondary } \\
1996-2005\end{array}$ & $\begin{array}{c}\text { Post- } \\
\text { secondary } \\
1996-2005 \\
\end{array}$ \\
\hline 16 & 1 & 0 & 0 & 2 & 0 & 0 \\
\hline 18 & 18 & 2 & 0 & 13 & 1 & 0 \\
\hline 20 & 46 & 16 & 6 & 40 & 9 & 1 \\
\hline 22 & 66 & 41 & 19 & 61 & 24 & 6 \\
\hline 24 & 78 & 61 & 34 & 77 & 41 & 14 \\
\hline 25 & 81 & 69 & 46 & 81 & 48 & 19 \\
\hline 26 & 82 & 74 & 51 & 83 & 55 & 25 \\
\hline 28 & 85 & 81 & 71 & 86 & 66 & 34 \\
\hline 30 & 88 & 86 & 79 & 88 & 72 & 52 \\
\hline 35 & 92 & 91 & 84 & 90 & 80 & 72 \\
\hline 40 & 93 & 92 & 86 & 91 & 82 & 77 \\
\hline mean age: & 22 & 23 & 25 & 22 & 25 & 28 \\
\hline \multicolumn{7}{|c|}{ (at transition, conditional on transition before age 40) } \\
\hline 1st decile: & 17 & 20 & 21 & 18 & 20 & 23 \\
\hline 1st quartile: & 19 & 21 & 23 & 19 & 22 & 26 \\
\hline median age: & 21 & 23 & 26 & 21 & 25 & 30 \\
\hline 3rd quartile: & 24 & 26 & 29 & 24 & 32 & 37 \\
\hline
\end{tabular}

A cohort perspective for first birth, by its' occurrence exposure rates (Figure 8.1), confirms the idea that first births in Romania changed more in intensity than in timing. The risks of having a first birth have similar age-patterns among women cohorts, with a maximum in the age group 22-25, and proportionally diminished at every age group for cohorts born in the 1970s. For men the landscape is slightly different. Men born in the early 1970s seem to keep the same level of primo-fertility at age 18-25 as older cohorts, but they diminished the first birth risk during their 26-29 years of age (by 50\%). Moreover, the youngest men cohort, born in the late 1970s, has halved the risk of first birth at age group 22-25, if compared to the earlier cohort. These reductions of men birth risks are due to the same period effect, i.e. the change in every apsects of life in the early 1990s. 
Figure 8.1: Occurrence / exposure rates for ever parent
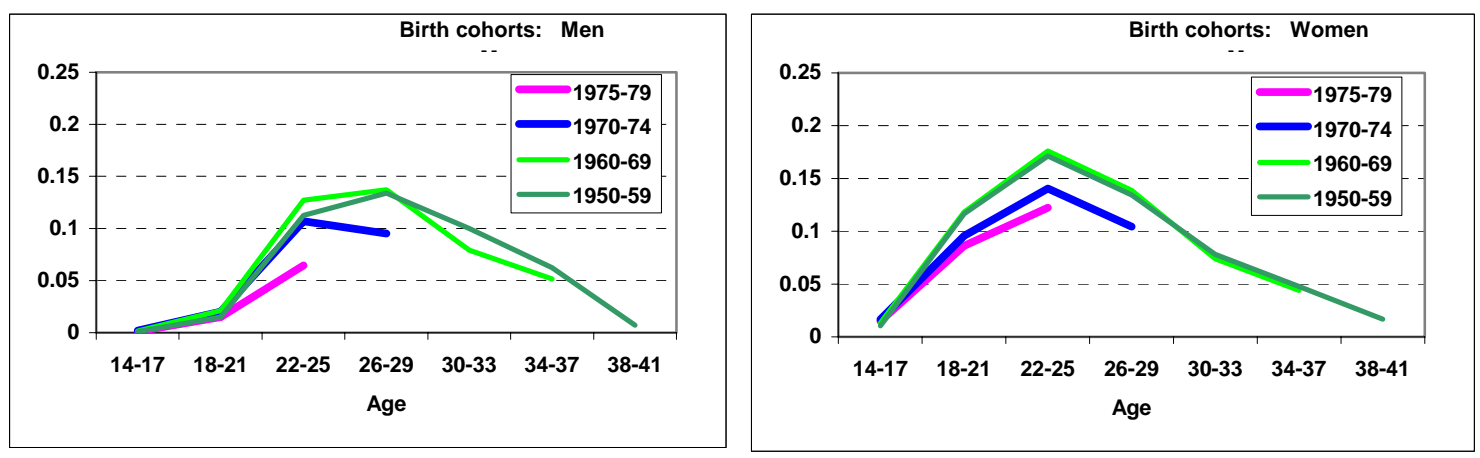

\section{Second birth}

If concerning first birth the three neighbour countries are more or less similar, as concerning the second birth Romanian women experienced it in a smaller proportion (58\%) than Bulgarian ones (68\%), at least during 1990-1994, even if the mean interval between the first two births was the same (almost 4 years). Unfortunately, we have no comparable data for Hungary.

Table 8.4: Cumulative percent of becoming parent for the second time, by duration after first birth (only biological children)

\begin{tabular}{lcccc}
\hline $\begin{array}{l}\text { Duration in years } \\
\text { after first birth }\end{array}$ & $\begin{array}{c}\text { Men } \\
\mathbf{1 9 8 0 - 1 9 8 9}\end{array}$ & $\begin{array}{c}\text { Men } \\
\mathbf{1 9 9 6 - 2 0 0 5}\end{array}$ & $\begin{array}{c}\text { Women } \\
\mathbf{1 9 8 0 - 1 9 8 9}\end{array}$ & $\begin{array}{c}\text { Women } \\
\mathbf{1 9 9 6 - 2 0 0 5}\end{array}$ \\
\hline & & & & \\
1 & 5 & 2 & 3 & 2 \\
2 & 24 & 11 & 24 & 12 \\
3 & 36 & 19 & 38 & 22 \\
4 & 46 & 27 & 48 & 29 \\
5 & 53 & 33 & 56 & 36 \\
7 & 60 & 42 & 63 & 46 \\
10 & 66 & 49 & 68 & 51 \\
15 & 69 & 53 & 71 & 54 \\
& & & & \\
mean duration & 3.6 & 4.8 & 3.8 & 4.6 \\
(at transition, conditional on transition before duration 15$)$ & & \\
& & & & \\
1st decile at dur: & 1 & 2 & 1 & 2 \\
1st quartile at: & 2 & 4 & 2 & 3 \\
median at dur: & 4.7 & 10.6 & 4.4 & 8.6 \\
3rd quartile at: & - & - & - & - \\
\hline
\end{tabular}


As for the first birth, the second birth suffered changes in level and timing. Table 8.4 lists life-table estimators by durations since first birth, showing that the second birth was delayed at every duration and an average postponement with one year happened. The mean interval between the first and the second birth increased from 4 to 5 years and the median increase was even larger (6 years for men and 4 years for women).

Futher evidence of patterns in second birth intensities is given by cohort data in Figure 8.2. The hazard rates by age group of one-child mothers (left hand side) shows a bigger reduction of second order fertility after age 30 than the reduction before this age for the cohorts born in the 1960s. We observe a further reduction of second birth risks before age 30 for women born in the 1970s. We cannot know yet how they will behave after age 30, but we can see on the right hand side of Figure 8.2, which shows duration-specific intensities, that their risk of second birth is higher during the second year or during the fifth year after the first birth, possibly reflecting some tempo changes in second births.

Nevertheless, the strong reduction in second birth level, from cohorts born in the 1950s, to those born in the 1960s, and further to those born in the 1970s, is evident especially at younger age-groups (22-25) and during the first three years following the first birth.

Figure 8.2: Occurrence / exposure rates for female second birth, by age of mother (left panel) or by duration since first birth (right panel)
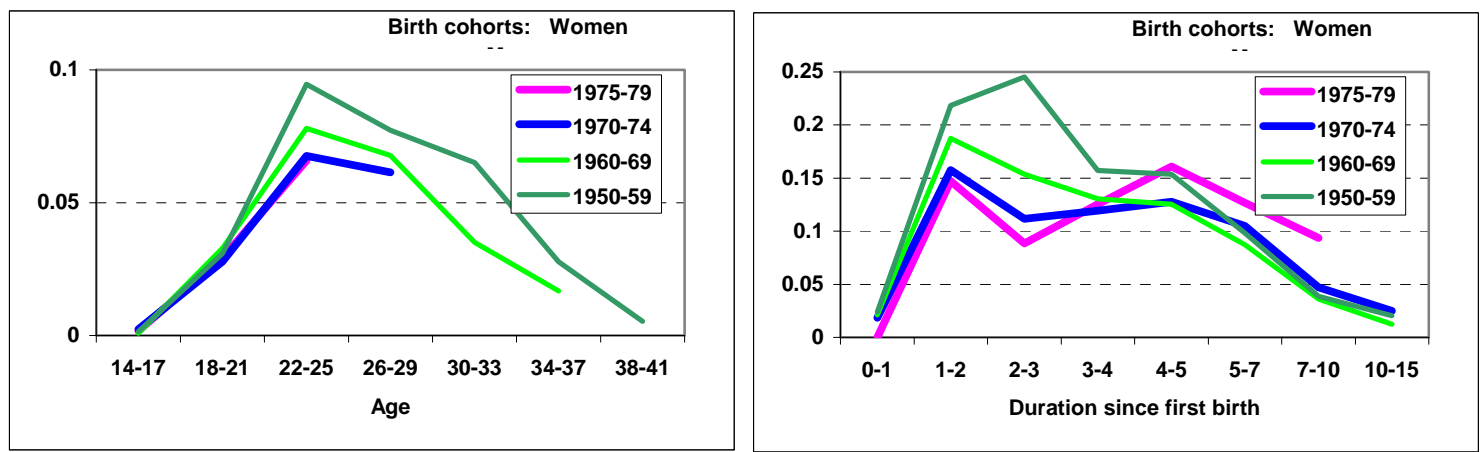

Evidently, fertility changes are not related with increasing share of the Roma population. Our sample contains only 185 Gypsies, representing $1.5 \%$. Roma population is the third ethnic group in GGS data, the second being Hungarians with 7.7\%, while Romanians are the majority with $89.7 \%$. The sample is representative of the entire Romanian population 
aged 18 and beyond, where the ethnic groups registered at the last census in 2002 share in the whole population as follows: $89.8 \%$ Romanians, $6.9 \%$ Hungarians, $1.8 \%$ Gypsies and $1.5 \%$ other minorities.

However, we present in Table 8.5 the hazard rates for second birth by four-year age groups and ethnic groups, based on the responses of one-child mothers. We had to use a unique calendar period, which includes all years from 1980 to 2005, in order to keep the statistical significance of the estimates. For the Roma ethnic group we also had to leave aside all rates estimates above age 30 because the number of population at risk passed below 15. The differences are impressive: Roma one-child mothers have four to nine times greater risks for a second birth in the age groups 18-21 than Romanians or Hungarians, almost three times higher risk in age group 22-25, and two times greater risks in age group 26-29. Their mean age at second birth (conditional on transition before age 40) is three years lower than for Romanians and three and a half years lower than for Hungarians. Concerning Romanian and Hungarian ethnic groups comparison we observe more similar risks in all age groups, but slightly later patterns for Hungarians: Until age 25 Romanians have higher risks of second birth and after this age Hungarians are more likely to give birth to a second child.

Table 8.5: Occurrence / exposure rates for second birth, by ethnic group (only biological children of women respondents)

\begin{tabular}{lccc}
\hline $\begin{array}{l}\text { Age of one-child } \\
\text { mother }\end{array}$ & $\begin{array}{c}\text { Romanian } \\
\mathbf{1 9 8 0 - 2 0 0 5}\end{array}$ & $\begin{array}{c}\text { Hungarian } \\
\mathbf{1 9 8 0 - 2 0 0 5}\end{array}$ & $\begin{array}{c}\text { Gypsy (Roma) } \\
\mathbf{1 9 8 0 - 2 0 0 5}\end{array}$ \\
\hline & & & \\
$14-17$ & 0.001 & 0.001 & 0.010 \\
$18-21$ & 0.020 & 0.010 & 0.087 \\
$22-25$ & 0.054 & 0.050 & 0.130 \\
$26-29$ & 0.051 & 0.061 & 0.103 \\
$30-33$ & 0.041 & 0.042 & - \\
$34-37$ & 0.019 & 0.029 & - \\
& & & 23.7 \\
mean age: & 26.5 & 27.3 & \\
(at transition, conditional on transition before age 40) & & \\
\hline
\end{tabular}

As regards differentiations by level of education (Table 8.6), we can see much more contrasting behaviors than in the case of first birth during socialist times, and an accentuation of contrasts in the more recent period. 
Table 8.6: Cumulative percent of becoming mother for the second time, by final educational level (only biological children of women respondents)

\begin{tabular}{|c|c|c|c|c|c|c|}
\hline $\begin{array}{l}\text { Duration } \\
\text { after first } \\
\text { birth }\end{array}$ & $\begin{array}{l}\text { No upper- } \\
\text { secondary } \\
1980-1989\end{array}$ & $\begin{array}{c}\text { Upper- } \\
\text { secondary } \\
1980-1989\end{array}$ & $\begin{array}{c}\text { Post- } \\
\text { secondary } \\
\text { 1980-1989 }\end{array}$ & $\begin{array}{l}\text { No upper- } \\
\text { secondary } \\
1996-2005\end{array}$ & $\begin{array}{c}\text { Upper- } \\
\text { secondary } \\
\text { 1996-2005 }\end{array}$ & $\begin{array}{c}\text { Post- } \\
\text { secondary } \\
\text { 1996-2005 }\end{array}$ \\
\hline 1 & 4 & 2 & 1 & 1 & 1 & 0 \\
\hline 2 & 32 & 19 & 21 & 22 & 9 & 5 \\
\hline 3 & 49 & 33 & 28 & 34 & 18 & 9 \\
\hline 4 & 59 & 43 & 35 & 44 & 25 & 14 \\
\hline 5 & 65 & 52 & 44 & 52 & 33 & 18 \\
\hline 7 & 71 & 61 & 51 & 63 & 42 & 24 \\
\hline 10 & 74 & 68 & 55 & 68 & 48 & 30 \\
\hline 15 & 77 & 71 & 59 & 70 & 52 & 32 \\
\hline mean duration & 4 & 4 & 4 & 4 & 5 & 5 \\
\hline \multicolumn{7}{|c|}{ (at transition, conditional on transition before duration 15) } \\
\hline 1st decile at dur: & 1 & 1 & 2 & 1 & 2 & 3 \\
\hline 1st quartile at: & 2 & 2 & 2 & 2 & 4 & 7 \\
\hline median at dur: & 3 & 5 & 7 & 5 & 12 & - \\
\hline 3rd quartile at: & 12 & - & - & - & - & - \\
\hline
\end{tabular}

More than three third of one-child mothers with lower-secondary educational level or less (77\%), and slightly fewer with upper-secondary educational level (70\%), had a second birth before 1990, but the higher educated ones had second births in a lower percentage. Nevertheless, the lowest cumulated percent of having a second birth was still as high as almost $60 \%$ for the highest educated women. This is not the case after 15 years of market times: Only one- third of highest educated women, half of middle-educated, and twothirds of low- educated women have a second birth.

Moreover, important changes took place in timing of second birth, noticeable especially thru an increasing differentiation in the median duration at birth. The lower the educational level is the sooner the second birth occurs, but the gap of median durations between lower-educated and middle-educated mothers, increased from 2 years to 7 . Highly educated two-children mothers have became scarcer during post-socialist times, therefore the median age can not be anymore calculated for them, but the first quartile shows as well the increasing differentiation in terms of timing at second birth by educational level. However, the mean interval between the first and the second birth 
changed only little, from 4 to 5 years, and only in the case of upper-secondary or higher educated women.

\section{Children experience}

Following the from-now-standard life-table representation scheme (Andersson and Philipov 2002) (Philipov and Jasilioniene 2007), we present some results from the child perspective. First we study the children's position in the family at their birth time, and then we check for the presence of both parents during childhood, which is of primary importance in studies of child development.

\section{Distribution of birth by union status of the parent}

Table 9.1 presents descriptive data of births by union status of the parent. The order of births is considered separately, and we also distinguish between men's and women's responses, and between socialist times (in our case calendar period 1980-1989) and market economy democratic times (1996-2005).

Some general statements that emerge from the Table 9.1 are:

- More than $80 \%$ of children are born in a first marriage with rare exception for higher order births in the recent period.

- More second order children are born in first marriages than first order or third order children. First order births are born increasingly in first cohabitations, while third order births are increasingly born in repeated unions.

- In the post-socialist period diversity of family statuses at the moment of birth increased.

Let us now describe differences and changes by union status. 
Lone parenting has two rows in the Table 9.1: births by lone parent and separated parent. Childbearing of separated fathers is non-existent and that of separated mothers is extremely rare. Only up to $1 \%$ of women give birth while separated and not (yet) in a new union, regardless of period or birth order. Lone parenting is a little bit more frequent at first birth: 4\% of first births were of lone parent during 1980-1989 and this percentage decreased during the more recent period 1996-2006 to $1 \%$ for men and to $3 \%$ for women. In Bulgaria there are relatively more births to lone parents ranging from $4 \%$ to $7 \%$, depending on period, and the trend is upward (Philipov and Jasilioniene 2007). In Hungary, 3\% of all births were from lone mothers during 1988-1993 (Andersson and Philipov 2002).

Table 9.1: Relative distribution of births (percent)

\begin{tabular}{lcccc}
\hline & $\begin{array}{c}\text { Men } \\
\text { 1980-1989 }\end{array}$ & $\begin{array}{c}\text { Men } \\
\text { 1996-2005 }\end{array}$ & $\begin{array}{c}\text { Women } \\
\mathbf{1 9 8 0 - 1 9 8 9}\end{array}$ & $\begin{array}{c}\text { Women } \\
\mathbf{1 9 9 6 - 2 0 0 5}\end{array}$ \\
\hline First order child & & & & \\
to a lone parent & 4 & 1 & 4 & 3 \\
to a separated parent & 0 & 0 & 1 & 1 \\
in a 1st cohabitation & 5 & 11 & 7 & 12 \\
in a 1st marriage & 89 & 86 & 86 & 83 \\
in a repeated union & 1 & 2 & 2 & 2 \\
& 100 & 100 & 100 & 100 \\
Second order child & & & & \\
to a lone parent & 1 & 0 & 2 & 1 \\
to a separated parent & 0 & 0 & 1 & 1 \\
in a 1st cohabitation & 4 & 6 & 4 & 7 \\
in a 1st marriage & 91 & 87 & 92 & 7 \\
in a repeated union & 3 & 7 & 2 & 100 \\
& 100 & 100 & 100 & 3 \\
Third order child & & & & 1 \\
to a lone parent & 1 & 0 & 2 & 8 \\
to a separated parent & 0 & 0 & 0 & 76 \\
in a 1st cohabitation & 5 & 8 & 6 & 12 \\
in a 1st marriage & 90 & 77 & 87 & 100 \\
in a repeated union & 4 & 15 & 5 & \\
& 100 & 100 & 100 & \\
\hline
\end{tabular}

Births within cohabitation are in an increasing trend. Relatively more children are born in cohabitation, regardless of the birth order. The largest increase is in the case of first births (from $5 \%$ to $11 \%$ for men, and from $7 \%$ to $12 \%$ for women), while for second order and 
third order births the increase is by $2 \%-3 \%$ from $4 \%$ in the case of second birth, and from $5 \%-6 \%$ in the case of third births. The more recent figures for first and second birth in the context of cohabitation are still far from the almost $25 \%$ out of wedlock births in the case of Bulgaria. Regarding the third birth, Romania (with around 10\%) differs from Bulgaria where non-marital birth proliferated to almost 40. For Hungary, we have no data detailed by birth order (nor by periods), but we know the share of births in cohabitation for 19881993: it was 6\% (Andersson and Philipov 2002).

Birth within the context of marriage is the most frequent, and especially within the first marriage, as we stressed above. However the trend is downward from $90 \%$ during socialist times to $80 \%$ during more recent times. The biggest change is for the third order birth ( $13 \%$ decrease in the case of men and $11 \%$ decrease in the case of women), while the decrease is only $3 \%$ for first order births and $8 \%$ for second order births.

Higher order births in repeated unions have a contrary trend to births during first marriages. The relative share of second births increased from $2 \%$ to $7 \%$ during the fifteen years that separate our periods of study, and the share of third birth increased from $5 \%$ to $12 \%$. Romania is similar to Bulgaria in respect to the recent share of first and second order births in repeated unions (around 3\% and 6\%, respectively) yet it lags Bulgaria in respect to the share of third births (where Bulgarian women declared 17\% of births). Unfortunately we have no similar data for Hungary.

\section{Children's experience of family disruption}

We saw in the preceding that most children are born in the context of union (married or cohabiting couples), but let us see how many and how long they remain together with both their parents. Table 9.2 gives the cumulated percent at age of child out of union for all children born in a union, regardless of birth order, and based on responses of all men and women. The death of a parent is considered as a censoring event.

A twice smaller proportion of children before age 15 experience their parents' separation: only $11 \%$ in the last decade (1996-2005) compared to $23 \%$ in the last decade of socialist 
regime (1980-1989). Moreover, their mean age at disruption increased by one year, from 8 to 9 years old. As we have shown earlier (in section 7), divorce have noting to do with this trend, since it did not decrease (the stability of marriage did not change over time), but the significant reduction in general fertility reduced the number of children born in any union (marriage or cohabitation) and the postponement of births delayed the moment when a child come into the life of a couple (see Table 6.5 for cumulative percent of parenting in first cohabitation and Table 7.4 for parenting in first marriage, for childless couples), reducing the experience of parents' separation in children's lives. Romania has fewer children in nowadays time, but they are more wanted by both their parents than before.

Table 9.2: Cumulative percent ever out of union, by age of child, for children born in a union

\begin{tabular}{lcc}
\hline Age of child & 1980-1989 & 1996-2005 \\
\hline 1 & 1 & 1 \\
2 & 2 & 1 \\
3 & 2 & 2 \\
4 & 3 & 3 \\
5 & 5 & 3 \\
7 & 8 & 5 \\
10 & 13 & 7 \\
15 & 23 & 11 \\
mean age: & 7.5 & 8.6 \\
(at union disruption / conditional on disruption during childhood) & \\
1st decile at age: & & 14 \\
1st quartile at: & 8 & - \\
median at age: & - & - \\
3rd quartile at: & - & - \\
& & 8 \\
mean duration: & 6 & \\
(of all episodes / truncated after 15 years) & & \\
\hline
\end{tabular}

In Bulgaria similar percentages were observed for the period 1990-2003, but the length of life until disruption is shorter by about one year. In Hungary (during 1988-1993) 22\% of children experienced parental disruption, i.e., a similar share as in socialist Romania (Andersson and Philipov 2002, p: 120). 


\section{Children's experience of family formation}

Even if children born to a lone or a separated and not (yet) repartnered parent are few, our sample disposes enough observations (see Table 2.1) to permit a life-table estimation of their experience of family formation (Table 9.3).

Table 9.3: Cumulative percent ever in union, by age of child, for children born to a lone mother

\begin{tabular}{lcc}
\hline Age of child & 1980-1989 & 1996-2005 \\
\hline & & \\
1 & 20 & 23 \\
2 & 33 & 27 \\
3 & 40 & 33 \\
4 & 45 & 33 \\
6 & 55 & 48 \\
9 & 63 & 56 \\
12 & 66 & 57 \\
15 & 68 & 60 \\
& & \\
mean age: & 3.9 & 4.3 \\
(at entry to union / conditional on union formation) & & \\
1st decile at age: & 1 & 0 \\
1st quartile at: & 1 & 1 \\
median at age: & 4.5 & 6.6 \\
3rd quartile at: & - & - \\
mean duration: & 5 & 6 \\
(of all episodes / truncated after 15 years) & & \\
\hline
\end{tabular}

Children born to a lone parent (essentially to a lone mother) experience in a greater proportion change in their status regarding the presence of one more parents (essentially a step father) than children born into a union experience separation of their parents. Twothirds of children born to a single parent have their status changed before age 15 in the period 1980-1989, and a little bit less (60\%) in the period 1996-2006. However, the difference between the cumulative percentages is not significant due to the small number of children born to a single parent in the sample. 
The mean age of children's transition to step children status did not changed, remaining at about 4 years, but the increased difference in median ages (from 4.5 to 6.6) shows a wider range of ages at transition to step children status in the most recent period.

In Bulgaria the level of transition to a new status of initially born to a lone parent, was $50 \%$ and the age at transition of the child was around 3 years (data from 1990-1994 synthetical cohort). In Hungary the share of ever in union, for children born to a lone mother, was similar (about 60\%) to the Romanian case, even if the event occured sooner in the child's life (during 1988-1993). For more details, one can see Philipov and Jasilioniene's (2007) and Andersson and Philipov's (2002) papers.

\section{Summary}

The 15 years of transition from an authoritarian regime and a centrally planned economy, toward a democratic political regime and a market-oriented economy, were doubled in Romania by significant demographic changes. Most of the "threshold levels" of the onset of the Second Demographic Transition were surpassed in the period 1991-1996, especially those concerning fall and long-lasting low fertility, postponement of childbearing and marriage, and drop in marriage rates. However, a few other "threshold levels" have not yet been surpassed: marriage is still stable, cohabitation is still marginal, ultimate celibacy is rare, and modern contraception is still underused.

The rough description of demographic changes, made with macro-level indicators, is enriched by life-table indicators, which compare diverse demographic developments from the last ten years of the socialist regime (1980-1989) to the ten years following the onset of the Second Demographic Transition (1996-2005).

Leaving the parental home is one of the first events considered as entry into adulthood, by the literature. In Romania leaving the parental home is universal among women and nearly universal among men, and starts relatively early in life. However, the change from one period to the other is not in a direction one would expect: The youth are not 
independent in a greater percentage nor earlier in life, and this suggests increasing difficulty to afford a separate home.

Housing difficulties in an east European context should be considered when one deals with entry into adulthood, thus, speaking about separating from the parental family instead of leaving the parental home, is a better approach. The former takes into consideration not only the physical leave of the parents' house, but also considers the formation of their own union while remaining in the parental home as a step toward independence. We found that the way of separating from the parental family is different between men and women: men use almost equally all three ways connected to union formation (leaving before union, leaving along with union, or forming a union in the parental home), while women most prefer to leave the parental home when they form a first union, and least prefer to form a union in their own parental home. As regarding the changes, we observed a shift from leaving the parental home for reasons not related to union formation, yet an increase in cases of forming a union at the home of parents in the case of men, and in the case of women we observed a reduction of leaving the parental home for other reasons than union formation. Both cases document for increased economic difficulties and less support from the state in housing policies.

Universal and early marriage featured Romania very long time. The universality of marriage is nearly lost for the synthetical cohort 1996-2005. Neither men nor women ever marry in a proportion close to $90 \%$, but women still have a level above 0.8 for first marriages. Instead, postponement toward older ages is firmly observed.

In the meantime, other forms of union have developed, and especially cohabitation. More and more people (and especially women) start a first union as cohabitation and they start it earlier than during socialist times. Conversely, direct marriages have declined, remaining, however, much more common than cohabitation, and much more common than in Bulgaria. Most cohabitation is a prelude to marriage, even if the share of cohabitations transformed into marriages decreased from socialist to post-socialist times. Instead, the number of split-up cohabitations more than doubled despite the longer duration of broken unions. 
Duration of marriage increased as well, and it increased in both cases of a broken marriage or a marriage ending by the death of one of the partners. We did not observe a substantial increase in first divorce.

Birth occurs very quickly after the first marriage, and even more quickly in a first union started as cohabitation, and the pattern changed very little between the two periods. Shotgun marriage, where the wedding follows pregnancy, remained at the same level as before.

Both marriage and childbearing were universal and early in Romania. Almost every woman had a child in the synthetical cohort corresponding to socialist times, even if in the case of men it was not so. Universality of motherhood weakened in post-socialist times, but still is above $80 \%$. As for marriages, the postponement of first birth to later ages is firmly observed.

Second order birth suffered even more changes in level and further postponement was noticed. Fewer and fewer women have a second child. Moreover, a polarisation of preferences took place: a category of very young mothers with two births emerged, partly compensating increasing preferences for the single-child family model.

The dynamic of family changes is completed by a children's perspective. More than $80 \%$ of children are born in a first marriage with rare exception for higher order birth in the more recent period. The changes concern increasing number of children born to cohabiting couples, especially first order children. Lone motherhood remains low, and lone fatherhood is almost non-existent. Children experience in a lower proportion their parents'disruption than in older-times.

To sum up, our life-table analysis confirms the early stage of the Second Demographic Transition in Romania. However, in European context it still remains a society highly valuing marriage and childbearing, despite the evidence in family behaviour changes which have accompanied political and socio-economical transformations after the fall of communist regime. 


\section{Acknowledgments}

I am grateful to Jan Hoem for his continuous encouragement and for his invitation to the Max Plank Institute for Demographic Research, which opened the way to work with Romanian Generations and Gender Survey data. I am also grateful to Dimiter Philiopov who introduced me to his Stata programmes, facilitating enormously the process of cleaning life-histories and programming life-table analysis with GGS data. Valuable comments to an earlier version of this study I have received from Gunnar Andersson and Hill Kulu and I am profoundly grateful to them. For technical advice I wish to thank Aiva Jasilioniene, and for language editing I am indebted to Yvonne Sandor.

\section{References}

Andersson G., Philipov D. (2002). "Life-table representations of family dynamics in Sweden, Hungary, and 14 other FFS countries: A project of descriptions of demographic behaviour." Demographic Research, Vol. 7, Article 4, Published 02 August 2002, pp. 67-270

Coviello, M., Boggess, M. (2004). "Cumulative incidence estimation in the presence of competing risks." Stata Journal, Vol. 4, No. 2, pp.103-112.

Council of Europe, (2004). Recent Demographic Developments in Europe 2004. Council of Europe, Strasourg

Hoem, J. (2001). Life table. In: N. Smelser and P. Baltes, (eds), International Encyclopedia of the Social and Behavioral Sciences. Elsevier, pp. 8832-8836

Lesthaeghe, R., Van de Kaa, D.J. (1985). “Twee demografische transities?”. In: D.J. Van de Kaa and R. Lesthaghe (eds). Bevolking: groei en krimp. Van Loghum Slaterus, Deventer, pp. 9-24.

Lesthaeghe, R. (1995). The Second Demographic Transition in Western countries: an interpretation. In: K.O.Mason and A.-M. Jensen(eds). Gender and Family Change in Industrialized Countries. Oxford: Claredon Press: pp. 17-62

Lesthaeghe, R. (1998). "On theory development: application to the study of family formation" Population and Development Review, Vol 24, No. 1, pp. 1-14 
Mureşan, C. (1999). Evoluția demografică a României (in Romanian). Cluj: Presa Universitară Clujeană.

Mureşan, C. (1999b) - "The decrease of life-expectancy at birth in Romania and some crisis contributing factors." Health \& Place, UK, 03092, Vol 5 Iss 2, pp. 187192

Mureşan, C. (2006). First pregnancy and reciprocal impact of abortion and fertility in Romania - European population Conference 2006 „Population Challenges in Ageing Societies", Liverpool, UK

Mureşan, C., Rotariu, T. (2000). "Recent Demographic Development in Romania”. In: T. Kucera, O.V. Kucerova, O.B. Opara, and E.Schaich (eds). New Demographic Faces of Europe. Berlin: Sprinter: pp. 267-85

Mureşan, C., Hărăguş, P.T., Hărăguş, M., Schroder, C. (2007). „Romania: childbearing methamorphosis within a changing context". In: T. Frejka (eds). Childbearing Trends and Policies, forthcoming

Philipov, D., Dorbritz J. (2003). Demographic Consequences of Economic Transition in Countries of Central and Eastern Europe. Population Studies, No. 39. Strasbourg: Council of Europe Publishing.

Philipov, D., Jasilioniene, A. (2007). „Unions and fertility in Bulgaria and Russia: a life table description of recent trends": MPI working paper

Preston, X., Heuveline, P., Guillot, M. (2001). Demography: Measuring and Modeling Population Processes. Blackwell, Oxford.

Rotariu, T. (2006). "Romania and the Second Demographic Transition. The Traditional Value System and Low Fertility Rates". International Journal of Sociology, Vol. 36, No.1 Spring, pp. 10-27

Sobotka, T., (2003). "Re-emerging diversity: Rapid fertility changes in Central and Eastern Europe after the collapse of the Communist regimes." Population (English Edition). Vol. 58, No. 4/5 (Jul.-Oct., 2003), pp.451-485 
Sobotka, T., Zeman, K., Kantarova, V., (2003). "Demographic shifts in the Czech Republic after 1989: a Second Demographic Transition view.” European Journal of Population, Vol.19, pp. 249-277

StataCorp, (2005). Stata Statistical Software: Release 9. User's Guide, College Station, Texas: StataCorp LP.

Van de Kaa, D.J. (1987) “Europe’s Second Demographic Transition“. Population Bulletin, Vol. 42, No.1

Van de Kaa, D.J. (2001) "Postmodern fertility preferences: from changing value orientation to new behaviour". In: R.A. Bulato and J.B. Casterline (eds). Global Fertility Transition. Supplement to Population and Development Review, No. 27, pp. $290-331$ 